This is the authors' copy of the final unpublished version of this manuscript. The Version of Record is available at:

https://doi.org/10.1016/j.cognition.2018.06.019

Please cite as:

Ziegler, J., \& Snedeker, J. (2018). How broad are thematic roles? Evidence from structural priming. Cognition, 179, 221-240.

\title{
How broad are thematic roles? Evidence from structural priming
}

Jayden Ziegler \& Jesse Snedeker

Department of Psychology, Harvard University

Jayden Ziegler (corresponding)

Dept. of Psychology

Harvard University

33 Kirkland St.

Cambridge, MA 02138

(908) 548-3384

ziegler@g.harvard.edu 


\begin{abstract}
Verbs that are similar in meaning tend to occur in the same syntactic structures. For example, give and hand, which denote transfer of possession, both appear in the prepositional-object construction: "The child gave / handed the ball to the dog." We can call the child a "giver" in one case and a "hander" in the other, or we can refer to her more generally as the agent, or doer of the action. Similarly, the dog can be called the recipient, and the ball, the theme. These generalized notions of agent, recipient, and theme are known as thematic roles. An important theoretical question for linguists and psycholinguists is what the set of thematic roles is. Are there a small number of very broad roles, perhaps with each one mapping onto a single canonical syntactic position? Or are there many distinct roles, several mapping to the same syntactic position but conveying subtly different meanings? We investigate this question across eleven structural priming experiments on Amazon Mechanical Turk (total N=2,914), asking whether speakers treat the thematic roles recipient and destination (i.e., location or spatial goal) as interchangeable, suggesting the broad role of goal, or distinct, suggesting two separate roles. To do so, we look for priming between dative sentences (e.g., "The man gave the ball to the dog”), which have a recipient role (dog), and locative sentences (e.g., "The man loaded hay onto the wagon"), which instead have a destination role (wagon). Our pattern of findings confirms that thematic role mappings can be primed independent of syntactic structure, lexical content, and animacy. However, we find that this priming does not extend from destinations to recipients (or vice versa), providing evidence that these two roles are distinct.
\end{abstract}

Keywords: structural priming; thematic roles; dative alternation; locative alternation; animacy 


\section{Introduction}

Linguistic theories posit systematic mappings between meaning (semantics) and form (syntax).

One such critical pattern of regularity is how participants in an event get mapped to syntactic positions, allowing us to reconstruct who did what in a sentence despite variations in surface word order. For example, if I tell you that "Beatrice glorped an orange to Dante," you know instantly that I'm describing an event in which an orange was transferred from Beatrice to Dante, even if you're fuzzy on exactly how this transfer was accomplished. This is because for a prepositional-object dative sentence like this one, the subject tells you who the agent, or doer, of the action is (Beatrice); the first object identifies the theme, or thing acted upon (orange); and the final, oblique argument indicates the recipient (Dante). These constructs (agent, theme, recipient, etc.) are known as thematic roles (Fillmore, 1968; Gruber, 1965; Jackendoff, 1972; for review and discussion, see Levin \& Rappaport Hovav, 2005). Had I instead said "Beatrice glorped Dante an orange," you would have arrived at the same interpretation, despite the different configuration of nouns, because different sentence types (constructions) have their own systematic mappings between thematic roles and syntactic positions (e.g., subject, object, etc.). ${ }^{1}$

A central and unresolved question in linguistics and psycholinguistics is what the set of thematic roles is. Are there a small number of very broad roles, perhaps with each one mapping onto a single canonical syntactic position? Or are there many distinct roles, several mapping to the same syntactic position but conveying subtly different meanings? The present paper explores the breadth of these thematic categories by looking closely at one example: the goal-like roles in

\footnotetext{
${ }^{1}$ These regularities can be formulated in many ways (e.g., Baker, 1988; Dowty, 1991; Fillmore, 1968; Fisher, Gleitman \& Gleitman, 1991; Gruber, 1965; Jackendoff, 1972, 1983, 1990; Levin, 1993; for review, see Levin \& Rappaport Hovav, 2005). In the present paper, we follow the convention in psycholinguistics and conceptualize them as mappings between thematic roles and syntactic positions.
} 
events of transfer of possession and caused motion. Consider, for instance, the prepositionalobject dative and theme-first locative sentences in (1).

(1) a. The boy hands the suitcase to his mother. (=prepositional-object dative)

b. The boy loads the suitcase on the cart. (=theme-first locative)

Both constructions have the same surface phrase structure (i.e., NP-V-NP-PP). Correspondingly, many theorists also assume parallel semantic representations across the two cases (e.g., Anderson, 1971; Baker, 1996; Harley, 2003; Goldberg, 1995, 2002, 2006; Gruber, 1965; Lakoff \& Johnson, 1980; Jackendoff, 1972, 1983; Pylkkänen, 2008). For instance, Jackendoff's (1983) Localist Hypothesis subsumes both of the prepositional arguments in (1), mother in (1a) and cart in (1b), under the same umbrella role of goal. We will refer to this possibility as the broad roles hypothesis. Other theorists maintain distinct semantic representations for the two prepositional phrase arguments, typically a recipient for prepositional-object datives and a destination for theme-first locatives (e.g., Bresnan \& Kanerva, 1989; Pinker, 1989; Rappaport Hovav \& Levin, 2008; for discussion, see Levin \& Rappaport Hovav, 2005). ${ }^{2}$ This we will call the narrow roles hypothesis. To address the viability of these two hypotheses, we turn to structural priming.

Structural priming is the tendency for speakers to reuse previously encountered sentence structures across utterances (Bock, 1986; for discussion, meta-analysis, and reviews, see Branigan, 2007; Branigan \& Pickering, 2017; Mahowald, James, Futrell, \& Gibson, 2016; Pickering \& Ferreira, 2008; Tooley \& Traxler, 2010). For instance, Bock (1986) showed that speakers were more likely to describe a picture with a prepositional-object dative ("The man is reading a story to the boy") following another prepositional-object dative ("A rock star sold

\footnotetext{
${ }^{2}$ Destinations are variously referred to as (spatial) goals or locations in the literature (for review, see Levin $\&$ Rappaport Hovav, 2005). To avoid confusion, either with the umbrella role goal or locations that are not specifically spatial goals, we use the term destination throughout this paper.
} 
some cocaine to an undercover agent") than following a double-object dative ("A rock star sold an undercover agent some cocaine"). Importantly, priming withstands variation in lexical items from prime to target and even variation in tense, aspect, and number (Bock, 1986; Pickering \& Branigan, 1998). Structural priming also does not result solely from parallels in metrical structure (Bock \& Loebell, 1990). For these reasons, psycholinguists use this priming to investigate the structural representations constructed during language production (Branigan \& Pickering, 2017).

\subsection{Structural priming as a window onto thematic structure}

For those familiar with this literature, it may seem counterintuitive to use structural priming to investigate thematic roles, since structural priming is often regarded as a largely syntactic phenomenon (e.g., Branigan, 2007; Branigan \& Pickering, 2017; Branigan, Pickering, Liversedge, Stewart, \& Urbach, 1995; Chang, Dell, \& Bock, 2006). However, a growing body of literature demonstrates that structural priming can occur on purely a thematic basis (e.g., Cai, Pickering, \& Branigan, 2012; Chang, Bock, \& Goldberg, 2003; Cho-Reyes, Mack, \& Thompson, 2016; Hare \& Goldberg, 1999; Köhne, Pickering, \& Branigan, 2014; Pappert \& Pechmann, 2014; Salamoura \& Williams, 2007; Yi \& Koenig, 2016; Ziegler, Snedeker, \& Wittenberg, 2017a). For example, Chang et al. (2003) found that speakers were more likely to produce theme-first locative sentences ("The farmer heaped straw onto the wagon") following other theme-first locatives ("The maid rubbed polish onto the table") relative to theme-second locative primes ("The maid rubbed the table with polish"), despite the two having the same surface syntax (both NP-V-NP-PP). Crucially, thematic structural priming persists even after factoring out several well-known confounds, including prepositional overlap, animacy cues, and 
morphosyntactic marking (Ziegler et al., 2017a). Thus, this priming can only be explained as priming based on the ordering of the thematic roles. By isolating this thematic component of priming from the influence of syntax, we will be able to address our central question.

But hasn't the specific question of whether recipients and destinations prime each other already been addressed? Indeed, Bock and Loebell (1990, Exp. 1) found that participants produced as many prepositional-object dative descriptions after motion verb sentences with locative prepositional phrases ("The wealthy widow drove an old Mercedes to the church") as after other prepositional-object dative primes ("The wealthy widow gave an old Mercedes to the church"), relative to a double-object dative baseline ("The wealthy widow gave the church an old Mercedes"). ${ }^{3}$ On the narrow roles hypothesis, church in the prepositional-object sentence is a recipient but a destination in the motion verb sentence. Yet the two led to equivalent priming, in accordance with the broad roles hypothesis. Importantly, however, both constructions also have the same surface syntax (both NP-V-NP-PP), while the double-object dative baseline Bock and Loebell (1990) used is different in both thematic and surface structure. Thus, this finding cannot distinguish between priming on the basis of thematic roles and priming based on syntax, or simultaneous priming of both structures. Moreover, some of the motion verbs Bock and Loebell (1990) used were actually non-alternating datives (e.g., return; see Levin, 1993), further muddying the intended distinction.

In a replication of this work, Potter and Lombardi (1998) did find, however, that prepositional-object dative primes led to a greater proportion of prepositional-object dative responses relative to motion verb primes. This is consistent with participants having treated the

\footnotetext{
${ }^{3}$ Bock and Loebell (1990) refer to these motion verb sentences as "(prepositional) locatives." However, we reserve the term locative for those change-of-location verbs, introduced in our discussion of Chang et al. (2003), that alternate between two sentence configurations (following, e.g., Levin, 1993; Pinker, 1989).
} 
thematic structures of the two sentences differently, despite their shared surface syntax.

Nevertheless, Potter and Lombardi’s (1998) motion verb sentences had inanimate location arguments (e.g., "Lenore drove her new convertible to the beach early this afternoon"), while their dative primes and targets had animate recipients (e.g., "The prompt secretary wrote a message to her boss every week"). We know that animacy can influence priming (see section 1.2 below). Thus, this finding is equally ambiguous. We return to these issues in Exp. $11 .^{4}$

There are two other phenomena that involve priming across constructions (crossstructural priming) which potentially address our question about the scope of thematic roles. The first is the much-replicated observation that benefactive constructions ("John baked a cake for Susan”) prime dative constructions (“John gave a cake to Susan”) (Bock, 1989; Chang et al., 2003; Pappert \& Pechmann, 2013). This observation could suggest that beneficiaries and recipients take the same thematic role, in support of the broad roles hypothesis. But these findings, like those in Bock and Loebell (1990) above, are also compatible with a purely syntactic explanation: prepositional-object structures prime other prepositional-object structures (e.g., "A cheerleader saved a seat for her friend" $\rightarrow$ "The girl is handing the paintbrush to the man on the ladder"), and double-object structures prime other double-object structures (e.g., "A cheerleader saved her friend a seat" $\rightarrow$ "The girl is handing the man on the ladder the paintbrush”) (Bock, 1989).

The final phenomenon, and the more informative one, is the priming of datives by fulfilling verbs, which either place the theme first (e.g., "John provided funds to the school”) or

\footnotetext{
${ }^{4}$ Salamoura and Williams (2007, Exp. 3) also investigated the priming of datives by transitive sentences with locative prepositional phrases. However, since their study investigated priming from one language to another, rather than within the same language, it is not clear how to interpret these results in the context of the current discussion. Nevertheless, although not significant across all comparisons, the authors observed the same general pattern of results as Potter and Lombardi (1998).
} 
second (e.g., "John provided the school with funds"). Hare and Goldberg (1999; also Cho-Reyes, Mack, \& Thompson, 2016; Salamoura \& Williams, 2007) found that, like double-object datives, theme-second fulfilling verbs (e.g., "His editor credited Bob with the hot story") resulted in more double-object dative responses to targets (e.g., "A man hands a woman a box of candy"), relative to a prepositional-object dative baseline (e.g., "His editor promised the hot story to Bob"). This cannot be due to priming of the surface syntax: theme-second fulfilling constructions have the same syntax as prepositional-object datives (i.e., NP-V-NP-PP) and a different surface structure from double-object datives. Thus, on the basis of syntax alone, theme-second fulfilling verbs should have led to an increase in prepositional-object dative responses, and a corresponding decrease in double-object dative responses. The results appear instead to reflect the ordering of thematic roles. As before, this suggests that the roles involved in these two constructions are similar enough to support priming, consistent with the broad roles hypothesis. However, these data do not provide substantial constraints on our theory of thematic roles. On the face of it, both verb classes appear to have post-verbal themes (entities transferred or possessed) and recipients (prototypically animate possessors; see, e.g., McIntyre, 2006; Rappaport Hovav \& Levin, 2008). Thus, even on a narrow construal of thematic roles, fulfilling verbs and datives have parallel roles and mappings. Consequently, the question of whether recipients and destinations belong to a single broader class remains open.

\subsection{Structural priming and animacy}

A related question concerns what the role of animacy is in these previous findings. Two things are clear. First, thematic role priming cannot be reduced to animacy. For example, in Chang et al. (2003), both post-verbal arguments were inanimate, and thus animacy was equated across the 
two constructions (see also Bernolet, Hartsuiker, \& Pickering, 2009; Carminati, van Gompel, Scheepers, \& Arai, 2008; Cho-Reyes et al., 2016; Huang, Pickering, Yang, Wang, \& Branigan, 2016; Köhne, Pickering, \& Branigan, 2014; Ziegler et al., 2017a). Second, it is also clear that animacy can influence priming (Bock, Loebell, \& Morey, 1992; Gámez \& Vasilyeva, 2015; for review and discussion, see Branigan, Pickering, \& Tanaka, 2008). For example, Bock et al. (1992) found that participants were more likely to use animates as subjects in their target descriptions, for both active and passive sentences, if the prime sentence also had an animate subject. Moreover, Gámez and Vasilyeva (2015) found that these influences interacted in children, such that passive priming was even greater when primes and targets matched in animacy features (e.g., both with animate patients) than when they mismatched (e.g., animate patient in one vs. inanimate patient in the other). Because datives, benefactives, and fulfilling verbs all have one animate post-verbal argument and one inanimate post-verbal argument, this leaves open the possibility that the cross-structural priming effects reviewed above (benefactiveto-dative, fulfilling-verb-to-dative) may well have been carried, in part or entirely, by these differential animacy cues rather than the thematic (or syntactic) structures alone. Cho-Reyes et al. (2016) controlled for the influence of animacy on fulfilling-verb-to-dative-priming by using fulfilling verb primes that had inanimate recipients (e.g., "The critic is crediting the restaurant with the dessert"). This created a mismatch in the animacy features of the recipient roles for the fulfilling verb primes and the dative targets. Crucially, priming persisted despite this mismatch, suggesting that it was the roles themselves that were primed and not the animacy features per se. However, the magnitude of priming appeared to be smaller with this mismatch (29\% vs. $22 \%) .^{5}$

\footnotetext{
${ }^{5}$ This magnitude difference was not significant, but with only 13 participants in total, their study was likely underpowered to detect the interaction (see, e.g., Mahowald et al., 2016).
} 
One straightforward interpretation of these findings is that animacy is an independent contributor to priming, such that priming is boosted if both thematic structure and animacy move in the same direction, but either component alone can create priming. This would be consistent with the findings for passives (e.g., Bock et al., 1992; Gámez \& Vasilyeva, 2015). Alternatively, it is also possible that animacy is a defining property of recipients (e.g., Goldberg, 1995), such that changing the animacy of the role filler completely changes the nature of the role itself. Under this type of account, Cho-Reyes et al.'s (2016) priming from fulfilling verbs to datives in the face of mismatching animacy features could have been due to participants interpreting the putatively inanimate recipient in the fulfilling verb sentences (e.g., restaurant) as referring to an animate entity (e.g., chef, restaurant staff, etc.), thereby equating the thematic roles across the two constructions (for related discussion pertaining to datives, see Harley, 2003). It therefore remains to be seen exactly whether and how changes in animacy of the recipient argument alter dative priming in particular. In the experiments that follow, we will explore the role of animacy in conjunction with and independent of thematic roles.

\subsection{Current study}

To more directly address how broad thematic roles are, we asked whether locative constructions would prime dative constructions (and vice versa). We chose these two verb classes because of the proposed distinction in their respective thematic roles on a narrow role construal: Locatives have a destination role and datives have a recipient role (Levin \& Rappaport Hovav, 2005). Importantly, destinations differ from recipients in several respects. Recipients are typically animate, and they must possess the theme, as in (2a); destinations (2b) do not need to meet either criterion (McIntyre, 2006; Rappaport Hovav \& Levin, 2008). In contrast, a destination is 
necessarily the physical locus of the theme at the end of the event (2b), while a recipient is not (2a) (Rappaport Hovav \& Levin, 2008).

(2) a. John bequeathed the castle to Alice.

b. John piled the books on the table.

If destinations and recipients are both instances of the broader role goal, in line with the broad roles hypothesis, then we should expect to see differences in priming between the two locative types on participants' dative productions and between the two dative types on participants' locative productions. Specifically, theme-first locatives should lead to a greater proportion of prepositional-object dative responses (and vice versa), since they both order their themes before their non-themes; and double-object datives should lead to a greater proportion of theme-second locative responses (and vice versa), since they both order their non-themes before their themes. If, however, destinations and recipients constitute distinct thematic roles, according to the narrow roles hypothesis, then we should observe no priming between locatives and datives. Importantly, in neither direction can syntax play a role. Both locative types have the same surface phrase structure as prepositional-object datives (NP-V-NP-PP), such that any differences we see in the priming of prepositional-object datives by locatives cannot be due to syntax. Conversely, both locative sentence types have a different phrase structure from double-object datives (NP-V-NP-PP vs. NP-V-NP-NP), so we also shouldn't see any differences in doubleobject dative productions on the basis of phrase structure either. Rather, only if thematic roles are broadly shared across locatives and datives do we expect any priming between the two classes.

But to ask this question, we must also consider the ways in which animacy interacts with thematic roles. Recall that our key contrast (locatives vs. datives) differs not only with respect to the putative thematic roles involved, but also with regard to the typical animacy features of the 
fillers of those roles. This raises the possibility that our results might reflect differences in animacy across our materials rather than properties of the thematic roles themselves. To address this concern, we also conduct two extensions of our locative-to-dative priming in particular. Specifically, we constructed locative prime sentences that have either animate destinations (e.g., "The boy sprayed the man with the cologne / the cologne on the man") or animate themes (e.g., "The girl loaded the trailer with the horses / the horses onto the trailer"), thus now matching the animacy features of the dative targets themselves (one animate argument, one inanimate argument), but in opposite directions.

In pursuing these critical cases, we also replicate five key findings in the literature on which they are built: (1) dative-to-dative priming (e.g., Bock, 1986), (2) locative-to-locative priming (e.g., Chang et al., 2003), (3) benefactive-to-dative priming (e.g., Bock, 1989), (4) fulfilling-verb-to-dative priming (e.g., Hare \& Goldberg, 1999), and (5) motion-verb-to-dative priming (Bock \& Loebell, 1990). Our motivations for replication are threefold. First, some of these findings have only been replicated a couple times (e.g., Bock \& Loebell, 1990; Chang et al., 2003; Hare \& Goldberg, 1999), sometimes with conflicting results (e.g., Potter \& Lombardi, 1998). Our critical experiments can only be interpreted if we are confident in the stability of these basic effects. Second, in the current studies, we switch from a lab-based production paradigm to an online paradigm using Amazon Mechanical Turk. These replications ensure that the known effects are present and robust in an online population. Finally, we need to be sure that the materials we have constructed reliably elicit the intended priming effects, thereby making any potential priming failures more interpretable.

A final critical feature of the present study is the large sample size and emphasis on selfreplication, both of which we hope will contribute to the stability of the literature on structural 
priming. Except for direct replications, we use a standard sample size of 172 participants per experiment (but 174 for Exp. 11), which is 2 to 6 times larger than most existing structural priming work. We also self-replicate all but 2 of our critical experiments (see below), with an even larger sample size of 300 in each case.

\section{Methods Overview}

All eleven experiments reported here were administered online via Amazon Mechanical Turk using psiTurk (Gureckis et al., 2016), both to increase sample size and to target a more representative cross-sectional population of English-speakers (as opposed to typical college convenience samples). Several of these replicate findings in the literature. Experiments 1 and 2 replicate priming within the two sets of constructions that are the focus of this paper (datives and locatives, respectively), validating our method and providing a baseline for the studies that follow. Experiment 3 explores priming within locatives in the face of conflicting animacy features from prime to target. Experiments 4 and 5 include the critical cross-structural cases of locative-to-dative priming and dative-to-locative priming, respectively. Experiments 6 and 7 verify that this kind of priming is independently motivated by replicating two key crossstructural priming effects within the literature. Experiments 8 and 9 reexamine locative-to-dative priming with matched animacy features from prime to target. Experiment 10 tests for crossstructural priming between fulfilling verbs and locatives. Finally, Exp. 11 revisits the priming of datives by motion verbs (i.e., Bock \& Loebell, 1990). To ensure the stability of our findings, we replicated all studies that were not direct replications (with the exception of Exps. 10 and 11, which produced clear and predicted effects). Each of these replications included an even larger sample size $(\mathrm{N}=300)$. (For a summary of all eleven experiments, see Table 1.) 


\begin{tabular}{|c|c|c|c|c|c|}
\hline Exp. & Prime Type & $\begin{array}{l}\text { Target } \\
\text { Type }\end{array}$ & Motivation & Priming & $\begin{array}{l}\text { Contributor(s) to } \\
\text { Priming }\end{array}$ \\
\hline 1 & Dative & Dative & $\begin{array}{l}\text { Replicate Bock } \\
\text { (1986) }\end{array}$ & $\begin{array}{l}31 \%, \\
p<.001^{*}\end{array}$ & $\begin{array}{l}\text { Syntax, narrow } \\
\text { thematic roles, and } \\
\text { animacy }\end{array}$ \\
\hline 2 & Locative & Locative & $\begin{array}{l}\text { Replicate and extend } \\
\text { Chang, Bock, \& } \\
\text { Goldberg (2003) }\end{array}$ & $\begin{array}{l}21 \%, \\
p=.004 *\end{array}$ & $\begin{array}{l}\text { Narrow thematic } \\
\text { roles }\end{array}$ \\
\hline 3 & $\begin{array}{l}\text { Locative (with } \\
\text { animate } \\
\text { destinations) }\end{array}$ & Locative & $\begin{array}{l}\text { Replicate and extend } \\
\text { Chang, Bock, \& } \\
\text { Goldberg (2003); test } \\
\text { for role of animacy }\end{array}$ & $\begin{array}{l}8 \%, \\
p=.004^{*} \\
(6 \%, \\
p=.03 *)^{\dagger}\end{array}$ & $\begin{array}{l}\text { Narrow thematic } \\
\text { roles }\end{array}$ \\
\hline 4 & Locative & Dative & $\begin{array}{l}\text { Test for priming of } \\
\text { broad roles }\end{array}$ & $\begin{array}{l}3 \%, p=.35 \\
(0 \%, \\
p=.96)^{\dagger}\end{array}$ & None \\
\hline 5 & Dative & Locative & $\begin{array}{l}\text { Test for priming of } \\
\text { broad roles }\end{array}$ & $\begin{array}{l}1 \%, p=.54 \\
(5 \% \\
p=.19)^{\dagger}\end{array}$ & None \\
\hline 6 & Benefactive & Dative & $\begin{array}{l}\text { Replicate Bock } \\
\text { (1989) }\end{array}$ & $\begin{array}{l}21 \%, \\
p<.001 *\end{array}$ & $\begin{array}{l}\text { Syntax, narrow } \\
\text { thematic roles, and } \\
\text { animacy }\end{array}$ \\
\hline
\end{tabular}




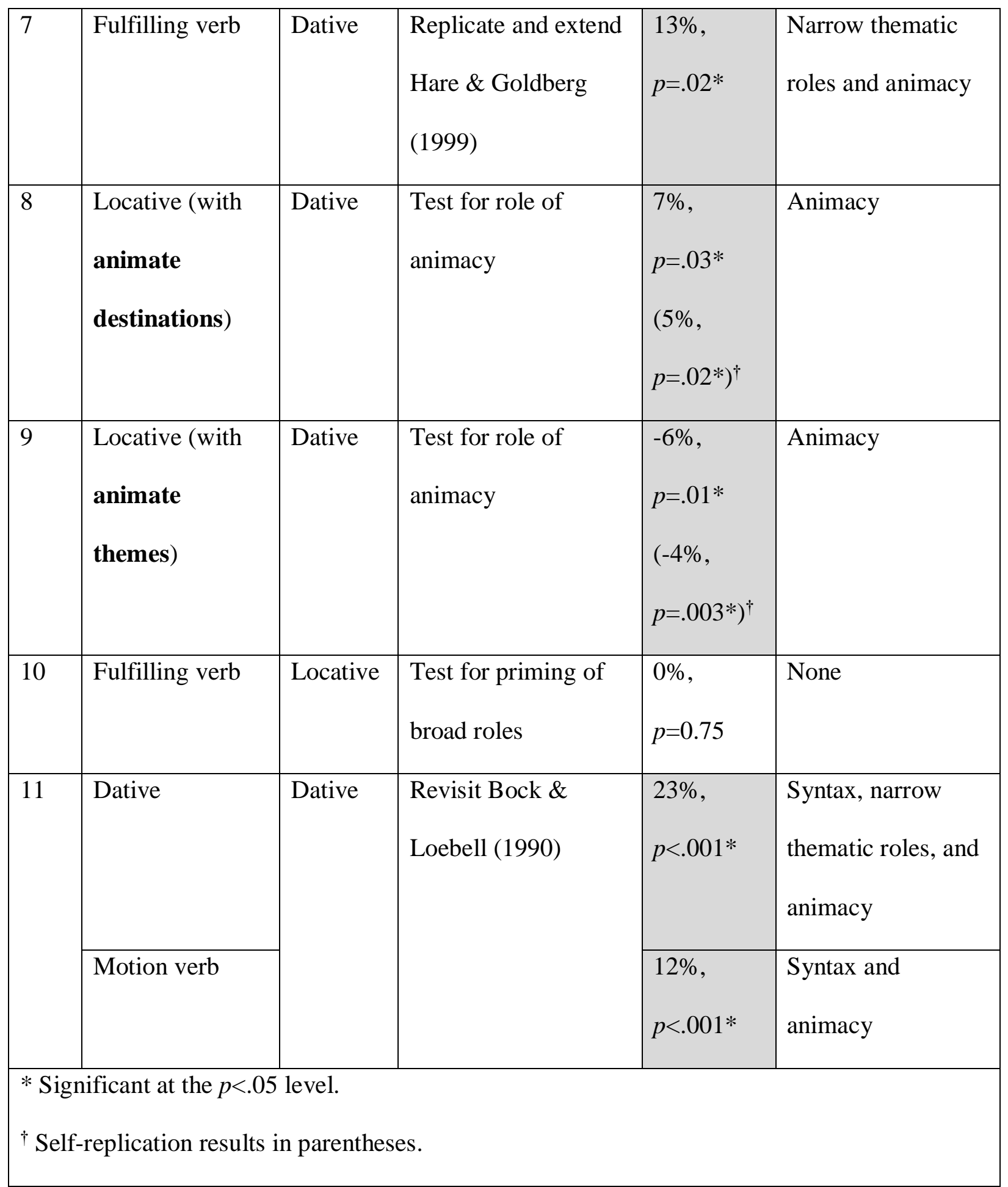

\subsection{Participants}


2,914 native English speakers recruited from Amazon Mechanical Turk participated in these experiments $(1,827$ female, 1,039 male, 15 trans, 17 unreported; mean age $=34[\mathrm{SD}=11]$, range $=18-77,61$ unreported). All participants provided written consent prior to participating and received $\$ 1.00$ for their participation.

\subsection{Materials}

\subsubsection{Experiments 1-10}

Each study consisted of 8 critical trials interspersed with 8 filler trials, for a total of 16 trials. All trials included a sequence of two prime sentences, presented verbally as audio clips, followed by a target animation, to be described by participants. Each prime sentence was paired with two cartoon still images. The images depicted two separate events, one consistent with the prime sentence and one distractor (a different event with the same agent). For within-structure priming (Exps. 1-3), primes and targets contained one of eight alternating verbs in one of two constructions, each appearing once as a target and twice as primes (in different pairings). For cross-structural priming (Exps. 4-10), primes and targets contained one of sixteen alternating verbs from two distinct classes (eight from one class for primes, each appearing twice, and eight from another for targets, each appearing once). In no case did verbs repeat within a trial. (For a summary of all constructions used, see Table 2.) Recipients (datives) were always animate. Destinations (locatives) were always inanimate for target animations, but varied in animacy by experiment for primes (see individual experiments for details). Themes (for both datives and locatives) were always inanimate for target animations, but also varied in animacy by experiment for primes (see individual experiments for details). All prime sentences were normed on Amazon Mechanical Turk for naturalness. Filler trials were the same across all experiments and contained 
direct objects with either one or two noun phrases (e.g., one: "The man bit the donut"; two: "The woman broke the plate and the jar"). All materials had one of four agents (boy, girl, man, woman), in equal proportions across items. ${ }^{6}$ Sentences were prerecorded by an adult male native English speaker (first author). (For a full list of all prime sentences and target animations by experiment, see Appendices A and B.)

We created four counterbalanced lists within each experiment. Within each list, half of the primes appeared in one form of the alternation, and the other half appeared in the other form. All lists began with a filler trial before the first critical trial, and alternated between filler and critical trials thereafter. There were never more than two critical trials of the same type back-toback (e.g., prepositional-object trial, filler trial, prepositional-object trial, etc.), and this occurred at equal frequency for one form of the alternation as for the other. Across lists, each target animation occurred an equal number of times with primes of one form as with primes of the other form, and an equal number of times in the first half of the experiment as in the second half of the experiment. All experiments followed this same list setup.

\subsubsection{Experiment 11}

The materials for Exp. 11 had the same basic structure as those for Exps. 1-10, except for the following changes. Rather than two prime sentence types, Exp. 11 had three: prepositional-object datives, double-object datives, and motion verb sentences with locative prepositional phrases. To keep the number of trials per condition consistent with the previous experiments, we added 4

\footnotetext{
${ }^{6}$ There were a few trials in which the agent in the second prime sentence was the same as that in the target animation ( $\leq 25 \%$ per experiment). However, it was never the case that any of the other content items (nouns or verbs) were repeated within a trial. Recent evidence (Scheepers, Raffray, \& Myachykov, 2017) suggests that repetition of even the agent argument alone can increase priming. To determine what effect this might have had, we reran each of our models coding for this factor. However, doing so did not alter the observed pattern of results. We therefore report only results of the models as described below.
} 
additional critical trials and 4 additional filler trials, for a total of 12 critical trials, 12 filler trials, and 24 overall trials. Items were counterbalanced across six rather than four lists, subject to the same constraints. The four additional filler trials had the same structure as before.

\begin{tabular}{|c|c|c|c|}
\hline Exp. & Verb & Construction & Example \\
\hline $\begin{array}{l}\text { Primes: } 1,5,11 \\
\text { Targets: } 1,4,6-9,11\end{array}$ & Dative & $\begin{array}{l}\text { Prepositional- } \\
\text { object / } \\
\text { double-object }\end{array}$ & $\begin{array}{l}\text { The woman fed the strawberry } \\
\text { to the goose / the goose the } \\
\text { strawberry. }\end{array}$ \\
\hline $\begin{array}{l}\text { Primes: } 2,4 \\
\text { Targets: } 2,3,5,10\end{array}$ & Locative & $\begin{array}{l}\text { Theme-first / } \\
\text { theme-second }\end{array}$ & $\begin{array}{l}\text { The boy sprayed the water on } \\
\text { the plant / the plant with the } \\
\text { water. }\end{array}$ \\
\hline Primes: 3,8 & $\begin{array}{l}\text { Locative (with } \\
\text { animate } \\
\text { destinations) }\end{array}$ & $\begin{array}{l}\text { Theme-first / } \\
\text { theme-second }\end{array}$ & $\begin{array}{l}\text { The boy sprayed the cologne } \\
\text { on the man / the man with the } \\
\text { cologne. }\end{array}$ \\
\hline Primes: 9 & $\begin{array}{l}\text { Locative (with } \\
\text { animate themes) }\end{array}$ & $\begin{array}{l}\text { Theme-first / } \\
\text { theme-second }\end{array}$ & $\begin{array}{l}\text { The girl loaded the horses onto } \\
\text { the trailer / the trailer with the } \\
\text { horses. }\end{array}$ \\
\hline Primes: 6 & Benefactive & $\begin{array}{l}\text { Prepositional- } \\
\text { object / } \\
\text { double-object }\end{array}$ & $\begin{array}{l}\text { The man ordered the pizza for } \\
\text { the lady / the lady the pizza. }\end{array}$ \\
\hline
\end{tabular}




\begin{tabular}{|l|l|l|l|}
\hline Primes: 7, 10 & Fulfilling verb & Theme-first / & The girl supplied the materials \\
theme-second & to the contractor / the \\
contractor with the materials.
\end{tabular}

\subsection{Procedure}

For prime trials, participants listened to the prerecorded sentences while viewing the cartoon images on a screen (Fig. 1). Participants were instructed to select which of the two images matched the sentence being played. Across all eleven experiments and five self-replications, participants were highly accurate (all $>97.9 \%$, overall $=99.1 \%$ ) on this task.

On target trials, participants were shown a three-second cartoon animation of an event, along with a word to be used to describe that event. This word was our target verb (dative or locative), and was presented to increase the likelihood that participants would use the intended constructions and decrease the likelihood of verb overlap between primes and targets. The target verb was displayed in capital letters above the animation (see Fig. 1). Participants' responses were recorded for later coding.

Figure 1. Procedure and example materials. 


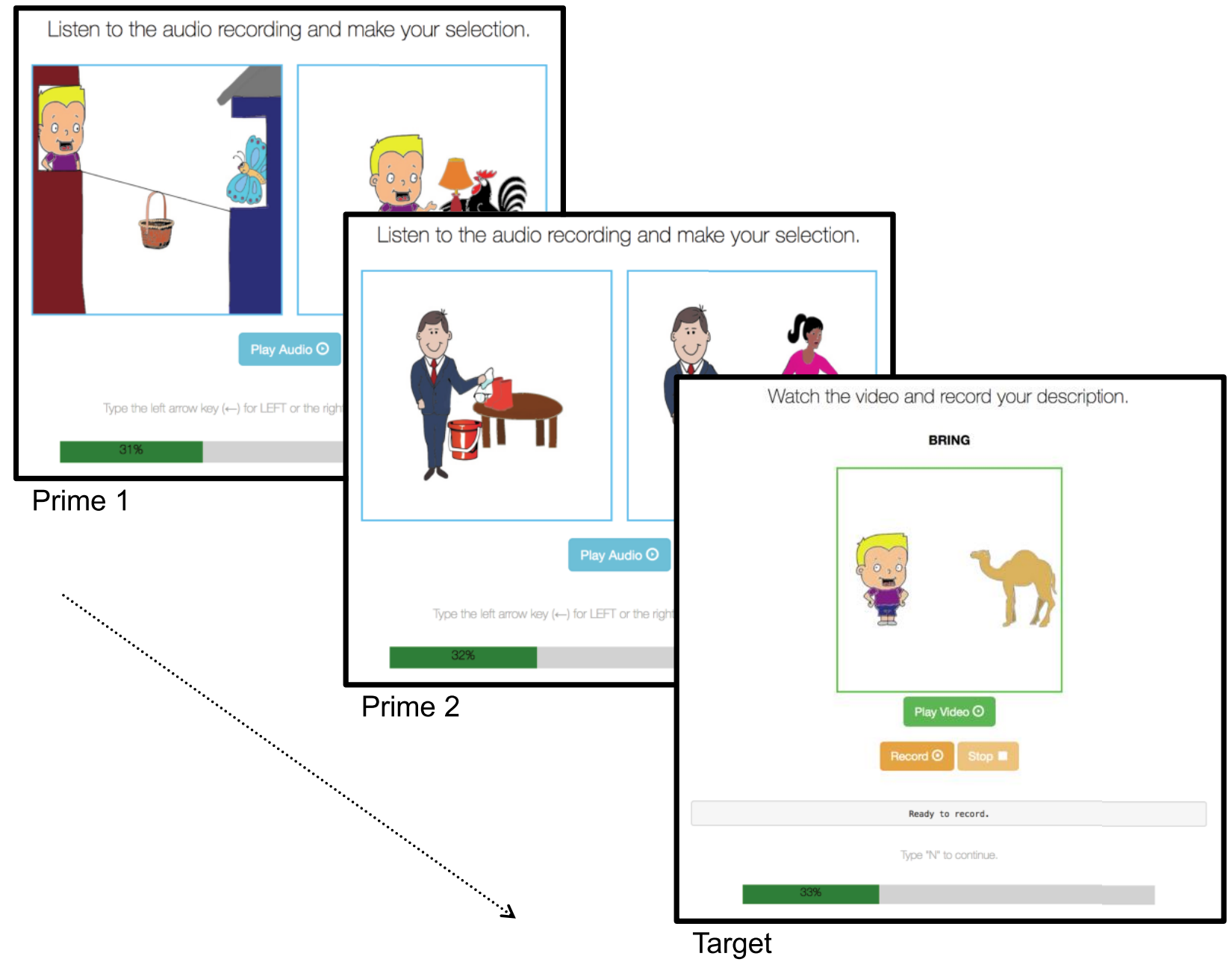

\subsection{Design}

For all experiments, the independent variable was Prime Type (Prepositional-object vs. Doubleobject for Exps. 1, 5, and 6; Theme-first vs. Theme-second for Exps. 2-4 and 7-10; Prepositionalobject vs. Double-object vs. Motion verb for Exp. 11), and the dependent measure was the number of prepositional-object datives (Exps. 1, 4, 6-9, 11) or theme-first locatives (Exps. 2, 3, 5,10 ) produced by participants (coded as 1 , with double-object datives/theme-second locatives coded as 0) out of all dative (prepositional-object+double-object) or locative (theme-first+themesecond) responses, respectively. In presenting the production cell means (for descriptive 
purposes), we have aggregated over both participants and items (prepositionalobject/prepositional-object+double-object, theme-first/theme-first+theme-second).

\subsection{Coding}

Participants' recorded responses were coded as "prepositional-object," “double-object," or "other" for dative targets, and as "theme-first," "theme-second," or "other" for locative targets. Prepositional-objects were sentences with a post-verbal THEME followed by the preposition to and a RECIPIENT. Any responses with this ordering that omitted the preposition to or used a different preposition altogether (e.g., at) were counted as other. Double-objects were sentences with a post-verbal RECIPIENT followed by a THEME, without any intervening prepositions. Theme-firsts were sentences with a post-verbal THEME followed by a locational preposition and a DESTINATION. Here we accepted the prepositions on(to), in(to), around (e.g., "The woman wrapped a bandage around the boy's arm”), and all over (e.g., "The boy smeared mud all over the house"). Finally, theme-seconds were sentences with a post-verbal DESTINATION followed by the preposition with and a THEME. Here the preposition was usually with, although we also counted in for the verb wrap (e.g., "The woman wrapped the boy's arm in a bandage"). All other forms were counted as other, including any responses that omitted an argument altogether or that included prepositions that were ambiguous or inconsistent with the expected thematic role (e.g., inside or behind). Responses in which participants used a different verb than we expected were included in the analysis so long as the verb produced was also an alternating dative or locative verb and was different from the verbs used in the primes (for Exps. 1-3). In total, 20,773 of the 23,665 target descriptions produced were dative $(94.9 \%)$ or locative $(76.6 \%)$ constructions and thus entered into the analysis, with no differences in the number of excluded trials by Prime 
Type within each experiment (Exp. 1: 2.5\% prepositional-object loss, 4.9\% double-object loss; Exp. 2: $17.9 \%$ theme-first loss, $20.9 \%$ theme-second loss; Exp. 3+replication: $22.2 \%$ theme-first loss, $20.5 \%$ theme-second loss; Exp. 4+replication: 5.7\% theme-first loss, 5.1\% theme-second loss; Exp. 5+replication: 25.3\% prepositional-object loss, 25.0\% double-object loss; Exp. 6: 5.4\% prepositional-object loss, 3.9\% double-object loss; Exp. 7: 6.4\% theme-first loss, 3.4\% theme-second loss; Exp. 8+replication: 6.6\% theme-first loss, 4.3\% theme-second loss; Exp. 9+replication: 4.2\% theme-first loss, 4.8\% theme-second loss; Exp. 10: 24.8\% theme-first loss, 25.7\% theme-second loss; Exp. 11: 4.8\% prepositional-object loss, 6.3\% double-object loss, 5.5\% motion verb loss). Twelve percent of the target responses for Exps. 1, 2, 6, and 7, and ten percent of the target responses for Exps. 3-5 and 8-11 were independently coded by a second coder. Intercoder reliability ratings were overall very high (all $>93.8 \%$, all Cohen's $\kappa s>.89$ ).

\subsection{Data analysis}

For each experiment, participants' productions were analyzed using a logistic mixed-effects model (Baayen, Davidson, \& Bates, 2008; Jaeger, 2008) in the lme4 package in R (Bates, 2010), with Prime Type as a fixed effect. We used the maximal random effects structure appropriate for this experimental design (Barr, Levy, Scheepers, \& Tily, 2013), including random intercepts for participant and item (target verb) and random slopes for Prime Type within both participants and items. Follow-up analyses for Exp. 11 were run on the same model, minus the relevant level of Prime Type. All fixed effects were effect coded $(1,-1)$. Confidence intervals were computed by running the confint function on the glmer model in the R stats package. ${ }^{7}$ Model goodness-offit $\left(R^{2}\right)$ was calculated on the correlation between fitted and observed values. ${ }^{8}$

\footnotetext{
${ }^{7}$ https://www.rdocumentation.org/packages/stats

${ }^{8}$ r2.corr.mer<-function $(\mathrm{m})\{$
} 
Where appropriate, we also looked for pairwise interactions of Prime Type by Experiment, when target trials were the same. For these analyses, our models included Prime Type, Experiment, and their interaction as fixed effects, with the same random effects structure as before. Both fixed effects were effect coded $(1,-1)$.

\section{Experiment 1: Replicating Bock (1986)}

Experiment 1 replicates Bock's (1986) finding of dative-to-dative priming. This finding has been frequently replicated (see Mahowald et al., 2016). Our goals in doing this are to validate our experimental paradigm and dative stimuli, and to provide a baseline for the priming effects in the subsequent experiments.

\subsection{Materials}

Prime and target stimuli for Exp. 1 used the following eight alternating dative verbs: bring, feed, give, hand, pass, send, show, and throw.

\subsection{Results}

As expected, Exp. $1(\mathrm{~N}=52)$ yielded a significantly increased proportion of prepositional-object dative productions following prepositional-object dative primes relative to double-object dative primes $(75 \%$ vs. $43 \%), \beta=.95(\mathrm{SE}=.16), z=5.94, p<.001,95 \% \mathrm{CI}[.65,1.32], R^{2}=.48$ (Fig. 2$)$.

\subsection{Discussion}

lmfit<-lm(model.response (model.frame $(\mathrm{m})) \sim$ fitted $(\mathrm{m}))$

summary(lmfit)\$r.squared $\}$ 
These results validate our dative materials and confirm that conducting structural priming studies online is a viable alternative to lab-based testing.

\section{Experiments 2 and 3: Replicating and Extending Chang et al. (2003)}

Experiments 2 and 3 replicate and extend Chang et al.'s (2003) locative findings and validate our locative stimuli. These studies make three contributions to the literature. First, locative priming has been studied far less than dative priming. To the best of our knowledge, the only published conceptual replication of Chang et al. (2003) is Yi and Koenig (2016). Critically, both Chang et al. (2003) and Yi and Koenig (2016) used a different paradigm than the Bock studies and our own experiments. In these studies, participants saw sentences presented rapidly and repeated them back (following Potter \& Lombardi, 1998). Thus, it is critical that we replicate locative priming in an event description task to establish the presence and magnitude of this effect.

Second, one limitation of Chang et al.'s (2003) stimuli is that most of the destinations they used were singular count nouns (e.g., table), while most of the themes they used were mass or plural nouns (e.g., polish, pins). We know that mass and plural nouns are similar to each other and distinct from count nouns (e.g., Chierchia, 1998), leaving open the possibility that priming in the original Chang et al. (2003) involved a mapping between these conceptual features of noun phrases and syntactic functions (for further discussion, see Chang et al., 2003). We addressed this possibility in Exp. 2 by varying our themes across the primes and targets, such that when the primes had mass themes the targets had discrete, non-plural themes, and vice versa (e.g., prime themes: water, lemonade; target theme: suitcase).

Third and finally, one key feature of locatives, in contrast to datives, is that both of their post-verbal arguments can be, and typically are, inanimate. Thus, locative priming cannot be 
explained as a mapping between animacy and word order. However, in our later experiments, we will be looking for priming between locatives and datives, which would require that priming persist despite animacy differences in the arguments. In Exp. 3, to ensure that this can occur when the construction and narrow thematic roles are held constant, we constructed locative primes with animate destinations and used targets with destinations that were inanimate (see below). Prior work on the role of animacy in priming has found that priming persists despite animacy mismatches from prime to target (Bock et al., 1992; Gámez \& Vasilyeva, 2015). Priming also clearly occurs even when animacy cannot be used as a reliable cue to argument order, as is true for the locatives (see also Bernolet et al., 2009; Carminati et al., 2008; ChoReyes et al., 2016; Huang et al., 2016; Köhne et al., 2014; Ziegler et al., 2017a). Thus, we expect to find priming in Exp. 3, in line with this past work. However, as reviewed above, animacy can also play a pivotal role in priming (Bock et al., 1992; Gámez \& Vasilyeva, 2015). Thus, introducing conflicting animacy features might well reduce the size of the priming effect. We will investigate this possibility by comparing the effects we find in Exp. 3 with those in Exp. 2 .

\subsection{Materials}

Prime and target stimuli for Exp. 2 used the following eight alternating locative verbs: load, pack, rub, smear, splash, spray, stuff, and wrap. Prime stimuli for Exp. 3 used the following eight alternating locative verbs: inject, load, pump, rub, splash, splatter, spray, and wrap. Target stimuli for Exp. 3 were the same as in Exp. 2. Prime sentences for Exp. 3 had animate destination and inanimate theme arguments (e.g., "The boy sprayed the man with the cologne / the cologne on the man"), while the target animations, as in Exp. 2, had inanimate destinations and inanimate themes (e.g., "Boy loading the cart with the suitcase / the suitcase on the cart"). 


\subsection{Results}

We found a significant increase in the proportion of theme-first locative productions following other theme-first locative primes, both for Exp. $2(\mathrm{~N}=52)(83 \%$ theme-first vs. $63 \%$ themesecond), $\beta=1.05(\mathrm{SE}=.37), z=2.85, p=.004,95 \% \mathrm{CI}[.51,2.24], R^{2}=.44$, and for Exp. $3(\mathrm{~N}=172)$ ( $80 \%$ theme-first vs. $72 \%$ theme-second), $\beta=.43(\mathrm{SE}=.15), z=2.90, p=.004,95 \% \mathrm{CI}[.14, .83]$, $R^{2}=.35$. A self-replication $(\mathrm{N}=300)$ of Exp. 3 yielded similar results $(80 \%$ theme-first vs. $73 \%$ theme-second), $\beta=.22(\mathrm{SE}=.10), z=2.17, p=.03,95 \% \mathrm{CI}[-.03, .43], R^{2}=.32$ (Fig. 2).

A comparison of the effects in Exp. 3+replication to those in Exp. 2 (total $\mathrm{N}=524$ ) yielded a significant Prime Type by Experiment interaction, $\beta=.23(\mathrm{SE}=.08), z=2.79, p=.005$, 95\% CI [.07, .41], $R^{2}=.34$, with priming in Exp. 2 greater than that in Exp. 3+replication (21\% vs. $7 \%)$.

\subsection{Discussion}

These results provide a conceptual replication of Chang et al. (2003) within a new paradigm and validate the sensitivity of our method and our locative materials. Moreover, we have demonstrated that locative priming occurs despite mismatches in animacy across primes and targets (Exp. 3 and its replication). Critically, we also found that priming is significantly reduced by these animacy mismatches. This accords with past work that has also found persistent, albeit reduced, priming in the face of conflicting animacy features (e.g., Gámez \& Vasilyeva, 2015).

\section{Experiments 4 and 5: Assessing the Priming of Broad Roles}


The central question of this paper is what the scope of thematic roles is. Are there a few very broad roles that each map to a single canonical syntactic position? Or are there many distinct roles, some of which map to the same syntactic structural position but convey different meanings? Having established the sensitivity of our paradigm and replicated the critical prior findings, we now address this question by looking at priming between locatives and datives. The broad roles hypothesis treats the thematic structures underlying both locatives and datives as the same (themes and goals), such that we should expect priming between the two classes. The narrow roles hypothesis, on the other hand, treats their thematic structures as distinct (themes and destinations for locatives vs. themes and recipients for datives), which, accordingly, should not yield priming between them. Exp. 4 assesses priming from locatives to datives, and Exp. 5 assesses priming from datives to locatives.

\subsection{Materials}

Prime stimuli for Exp. 4 were the same as in Exp. 2. Target stimuli for Exp. 4 were the same as in Exp. 1. Prime stimuli for Exp. 5 were the same as in Exp. 1. Target stimuli for Exp. 5 were the same as in Exps. 2 and 3.

\subsection{Results}

Participants in Exp. $4(\mathrm{~N}=172)$ produced equivalent proportions of prepositional-object datives following theme-first locative primes as following theme-second locative primes (69\% vs. 66\%), $\beta=.09(\mathrm{SE}=.10), z=.94, p=.35,95 \% \mathrm{CI}[-.15, .32], R^{2}=.55$, and participants in Exp. $5(\mathrm{~N}=172)$ produced equivalent proportions of theme-first locatives following prepositional-object dative primes as following double-object dative primes (79\% vs. $78 \%), \beta=-.09(\mathrm{SE}=.15), z=-.61, p=.54$, 
$95 \%$ CI $[-.55, .20], R^{2}=.47$. Self-replications (each $\mathrm{N}=300$ ) of both experiments yielded similar results: Exp. 4 (64\% theme-first vs. 64\% theme-second), $\beta=.01(\mathrm{SE}=.11), z=.05, p=.96,95 \% \mathrm{CI}[-$ $.25, .28], R^{2}=.49$; Exp. 5 (81\% prepositional-object vs. $76 \%$ double-object), $\beta=.14(\mathrm{SE}=.10)$, $z=1.30, p=.19,95 \%$ CI $[-.12, .41], R^{2}=.37$ (Fig. 2 ).

Priming in Exp. 5+replication was significantly less than priming in Exp. 3+replication $(4 \%$ vs. $7 \%),($ total $\mathrm{N}=944) \beta=.08(\mathrm{SE}=.04), z=2.23, p=.03,95 \%$ CI $[.01, .16], R^{2}=.36 .{ }^{9}$

Figure 2. Overall proportions of prepositional-object datives and theme-first locatives by Prime Type by experiment (including self-replication data). Error bars reflect by-subject standard errors. $\mathrm{PO}=$ propositional-object; $\mathrm{DO}=$ double-object; $\mathrm{TF}=$ theme-first; $\mathrm{TS}=$ theme-second;

$$
\mathrm{MV}=\text { motion verb. }
$$

\footnotetext{
${ }^{9}$ We did not compare Exps. 1 and 4 because the prime sentences in each differ on more than just their thematic role configurations (e.g., syntax, animacy).
} 

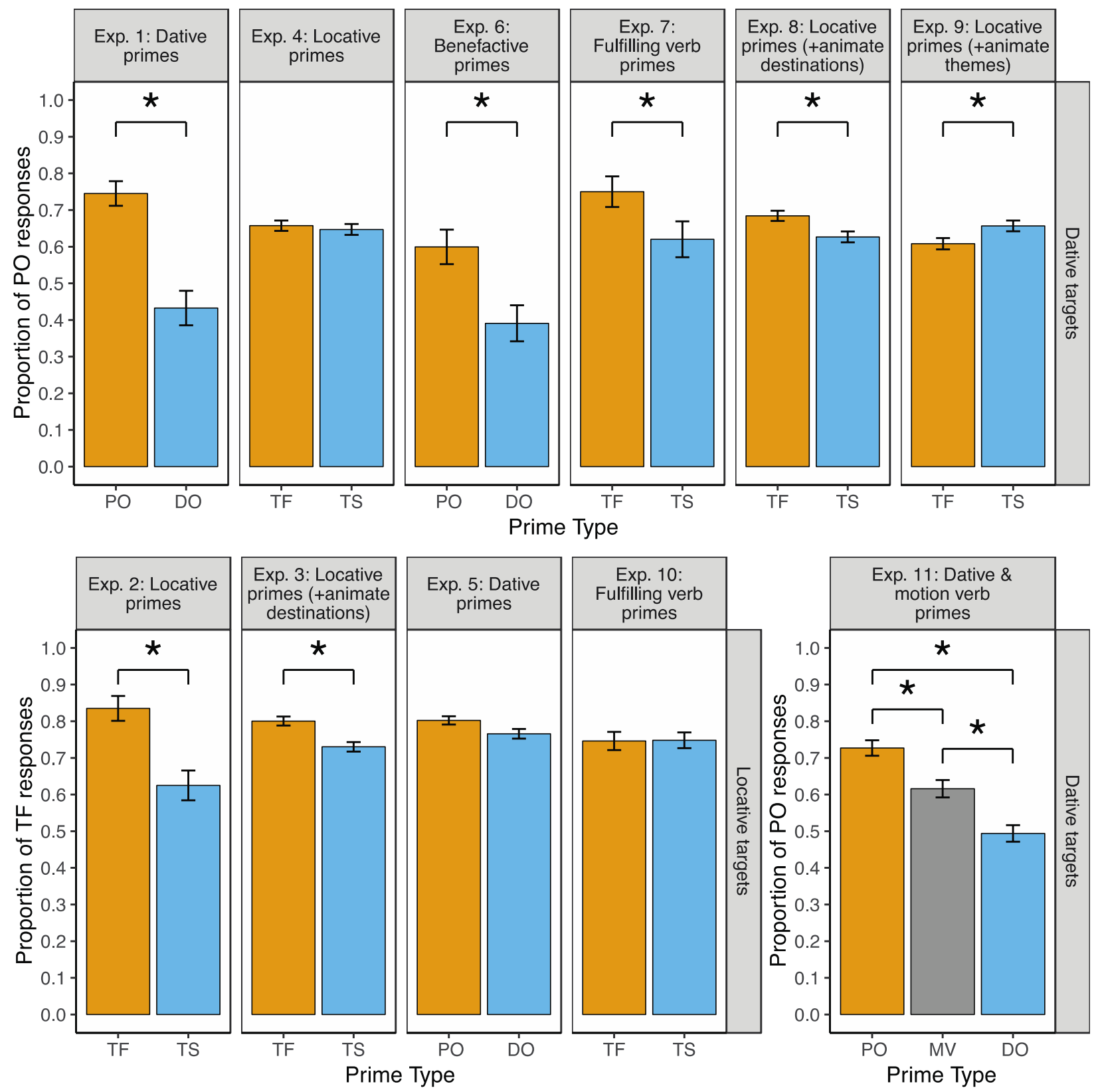

\subsection{Discussion}

We found no evidence that locatives prime datives (Exp. 4) or that datives prime locatives (Exp.

5). Critically, the comparison between Exp. 5 and its closest control, Exp. 3, resulted in a reliable interaction: Locative primes with animacy mismatches (Exp. 3) have a reliably greater effect on other locatives than datives do (Exp. 5). Since the two forms of the locative share a syntactic 
structure, and since the animacy mismatches between prime and target are the same for these two studies, the critical difference between Exps. 3 and 5 is in the nature of their thematic roles (the question at the heart of this paper). When the narrow thematic roles match (e.g., locative-tolocative), we get priming; when they do not match (e.g., dative-to-locative), we get no priming. This suggests that the recipient role for datives and the destination role for locatives are distinct, in line with the narrow roles hypothesis.

However, there is a second difference between these two experiments that we must address. In Exp. 3, we are priming within the same construction (locatives), while in Exp. 5 (and Exp. 4), we are priming between two different constructions (datives and locatives). This raises the possibility that thematic priming occurs solely within specific constructions (specified for both their syntactic and thematic features) but not across constructions (cross-structurally). Exps. 6 and 7 begin to address this concern.

\section{Experiments 6 and 7: Replicating Bock (1989) and Hare \& Goldberg (1999)}

Experiment 6 replicates Bock's (1989) benefactive-to-dative findings, while Experiment 7 replicates and extends Hare and Goldberg's (1999) fulfilling-verb-to-dative findings. As mentioned in the Introduction, the interpretation of our critical experiments requires that priming across constructions (cross-structural priming) be robust and sensitive to thematic role mappings. These replications serve to verify both the robustness of cross-structural priming in the current paradigm (Exps. 6 and 7) and its sensitivity to thematic role ordering in particular (Exp. 7). We extend Hare and Goldberg (1999) in the following way. Their original study and the two subsequent replications (Salamoura \& Williams, 2007; Cho-Reyes et al., 2016) have used only the theme-second variant of fulfilling verbs (e.g., "His editor credited Bob with the hot story"), 
relative to a prepositional-object dative baseline (e.g., "His editor promised the hot story to Bob"). Here we directly contrast the theme-second variant of fulfilling verbs with its theme-first counterpart (e.g., "His editor credited the hot story to Bob"). This is critical to ensure that it is the thematic ordering that accounts for the cross-structural priming in this case.

\subsection{Materials}

Prime stimuli for Exp. 6 used the following eight alternating benefactive verbs: bake, buy, fetch, find, get, make, order, and save. Prime stimuli for Exp. 7 used the following eight alternating fulfilling verbs: credit, entrust, issue, leave, present, provide, serve, and supply. Target stimuli for Exps. 6 and 7 were the same as in Exps. 1 and 4.

\subsection{Results}

As expected, participants in Exp. $6(\mathrm{~N}=52)$ produced significantly more prepositional-object datives following prepositional-object benefactive primes relative to double-object benefactive primes $(60 \%$ vs. $39 \%), \beta=.77(\mathrm{SE}=.16), z=4.79, p<.001,95 \% \mathrm{CI}[.44,1.16], R^{2}=.57$, and participants in Exp. $7(\mathrm{~N}=52)$ produced significantly more prepositional-object datives following theme-first fulfilling verb primes over theme-second fulfilling verb primes (75\% vs. 62\%), $\beta=.64(\mathrm{SE}=.28), z=2.26, p=.02,95 \%$ CI $[.09,1.36], R^{2}=.65$ (Fig. 2).

Priming in Exp. 6 was not significantly different from priming in Exp. 1 (21\% vs. 31\%), (total $\mathrm{N}=104) \beta=.15(\mathrm{SE}=.10), z=1.48, p=.14,95 \% \mathrm{CI}[-.05, .35], R^{2}=.51$. Priming in Exp. 7 was, however, significantly less than priming in Exp. 1 (13\% vs. 31\%), (total $N=104) \beta=.28(\mathrm{SE}=.11)$, $z=2.67, p=.008,95 \%$ CI $[.08, .50], R^{2}=.50$, and significantly greater than priming in Exp. 
$4+$ replication $(13 \%$ vs. $1 \%)$, (total $\mathrm{N}=524) \beta=-.25(\mathrm{SE}=.07), z=-3.36, p<.001,95 \%$ CI $[-.41,-.10]$, $R^{2}=.52$.

\subsection{Discussion}

These results confirm that the present paradigm is sensitive to priming across constructions (cross-structural priming), using two different contrasts. First, we have replicated Bock (1989; also Chang et al., 2003; Pappert \& Pechmann, 2013), showing priming from benefactives to datives (Exp. 6). Second, we have replicated and extended Hare and Goldberg (1999; also Salamoura \& Williams, 2007; Cho-Reyes et al., 2016), showing priming from fulfilling verbs to datives (Exp. 7). As noted in the Introduction, however, benefactive-to-dative priming could well be due to surface syntax alone, since prepositional-object benefactives and prepositional-object datives share one constituent structure (i.e., NP-V-NP-PP), while double-object benefactives and double-object datives share another (i.e., NP-V-NP-NP). Critically, priming from fulfilling verbs to datives cannot be explained in this way: Both variants of fulfilling verbs share the same surface syntax. But they have different thematic mappings: theme-first fulfilling verbs have the same thematic ordering as prepositional-object datives, while theme-second fulfilling verbs have the same thematic ordering as double-object datives. Thus, Exp. 7 provides strong evidence for the influence of thematic roles on cross-structural priming, thereby strengthening our results in Exps. 4 and 5.

We also observed a difference in the magnitude of priming in these two experiments. Benefactives (Exp. 6) primed datives as strongly as other datives did (Exp. 1). In contrast, fulfilling verbs primed datives to a lesser degree (Exp. 7). We suspect that this reflects differences in the degree to which the prime and target structures share surface syntax. Past work 
investigating the relative contributions of the different structural representations to priming (e.g., thematic roles, surface syntax, animacy, information structure, etc.) suggests that priming is cumulative, possibly even additive (e.g., Bernolet, Colleman, \& Hartsuiker, 2014; Bernolet et al., 2009; Gámez \& Vasilyeva, 2015; Griffin \& Weinstein-Tull, 2003; Vernice, Pickering, \& Hartsuiker, 2012; Ziegler et al., 2017a). For example, in our prior work, we found increased priming in dative constructions with strong thematic overlap above and beyond the influences of surface syntax, prepositional overlap, morphosyntax, and animacy (Ziegler et al., 2017a). In short, the more features that align from prime to target, the greater the priming effect. Benefactives are parallel to datives in surface structure, animacy, and likely thematic structure; thus, we expect similar levels of priming. In contrast, while fulfilling verbs and datives have the same mappings of both animacy features and thematic roles to surface positions, they do not share a syntactic structure, yielding less priming. Our finding of enhanced priming in locatives when animacy features matched (Exps. 2 and 3) is also perfectly in line with this notion.

Critically, cross-structural priming between fulfilling verbs and datives (Exp. 7) was also substantially greater than that between locatives and datives (Exp. 4). However, these two experiments are not a minimal pair: In addition to the putative thematic structural differences between the two cases (recipients for both fulfilling verbs and datives but destinations for locatives), Exp. 7 also has parallel animacy-to-linear-order mappings among primes and targets (animate entity to first object vs. second), while Exp. 4 does not. Accordingly, animacy (either alone or in combination with thematic structure) may play a crucial role in dative priming. We explore this possibility in Exps. 8 and 9. 


\section{Experiments 8 and 9: Reassessing Locative-to-Dative Priming with Parallel Animacy}

\section{Features}

To investigate the role that animacy features play in priming involving dative constructions, Exp. 8 asks whether there is locative-to-dative priming when the destinations in locatives share the same animacy features as the recipients in datives. To do this, we used the locative primes with animate destinations from Exp. 3.

Successful priming in this case would, of course, be consistent with at least two possible interpretations. On the one hand, animacy could be an entirely independent contributor to dative priming, in line with the passive results (e.g., Bock et al., 1992; Gámez \& Vasilyeva, 2015). Accordingly, matching animacy features from prime to target may well be sufficient to carry priming from locatives to datives, even if the thematic structures are different. If this were so, and assuming additivity of the priming effects, we might expect priming in Exp. 8 to be significantly less than that in Exp. 7, because the priming in Exp. 7 would be based both on shared thematic structure and shared animacy mappings while that in Exp. 8 would be based on shared animacy mappings alone. The alternative is that locatives and datives do in fact share a broad goal role, but that the nature of this role is very sensitive to the animacy features of the nouns filling it. If this were so, we might expect that by changing the animacy of the destinations in the locatives we've now created parallel thematic structures across the two constructions (both with animate goals), thereby yielding equivalent levels of priming to Exp. 7. Note that our finding of enhanced priming in locatives when animacy features matched (Exps. 2 vs. 3) is broadly consistent with either interpretation. On the one hand, priming may have been enhanced for Exp. 2 because of the shared combination of thematic structure and animacy mappings compared to just the shared thematic structure in Exp. 3. On the other hand, changing the 
animacy of the destination role (Exp. 3) may have fundamentally changed the nature of the role itself (though, curiously, not so much so as to wipe out the priming entirely).

To further address this question, we also constructed locative primes with animate themes instead of destinations (Exp. 9), thus equating the animacy features between the datives and the locatives (one animate argument, one inanimate argument) but only when the thematic roles are misaligned (locative themes with dative recipients, locative destinations with dative themes). Specifically, theme-first locatives with animate themes (e.g., "The girl loaded the horses onto the trailer") are now parallel in animacy-to-linear-order mappings (animate before inanimate) to double-object datives rather than prepositional-object datives, while theme-second locatives with animate themes (e.g., "The girl loaded the trailer with the horses") now have parallel animacy mappings with prepositional-object datives instead of double-object datives. If animacy is a fully independent source of priming, then we should expect to see, somewhat counterintuitively, a decrease in prepositional-object dative productions following theme-first locatives with animate themes, and a corresponding increase in double-object dative productions following themesecond locatives with animate themes. This pattern would be in direct opposition to the predictions of the broad roles hypothesis. If, on the other hand, animacy is a key factor defining broad thematic roles, but does not exert its own independent influence, then we should expect to see successful priming in Exp. 8, as hypothesized above, but not in Exp. 9.

\subsection{Materials}

Prime stimuli for Exp. 8 were the same as in Exp. 3. Prime stimuli for Exp. 9 used the following eight alternating locative verbs: cram, drape, load, pack, pile, stock, stuff, and wrap. Target stimuli for Exps. 8 and 9 were the same as in Exps. 1, 4, 6, and 7. As in Exp. 3, prime sentences 
for Exp. 8 had animate destination and inanimate theme arguments (e.g., "The boy sprayed the man with the cologne / the cologne on the man"), parallel to the target dative animations' animate recipients and inanimate themes (e.g., "Boy bringing the camel the keys / the keys to the camel"). Prime sentences for Exp. 9 had animate theme and inanimate destination arguments (e.g., "The girl loaded the trailer with the horses / the horses onto the trailer"), oppositely parallel to the target dative animations' animate recipients and inanimate themes.

\subsection{Results}

Participants in Exp. $8(\mathrm{~N}=172)$ produced significantly more prepositional-object datives following theme-first locative primes with animate destination roles over theme-second locative primes $(68 \%$ vs. $61 \%), \beta=.22(\mathrm{SE}=.10), z=2.22, p=.03,95 \% \mathrm{CI}[-.01, .45], R^{2}=.50$. Participants in Exp. 9 (N=172), conversely, produced significantly fewer prepositional-object datives following theme-first locative primes with animate theme roles over theme-second locative primes (58\% vs. $64 \%), \beta=-.22(\mathrm{SE}=.09), z=-2.50, p=.01,95 \% \mathrm{CI}[-.41,-.04], R^{2}=.55$. Self-replications (each $\mathrm{N}=300$ ) of both experiments yielded similar results: Exp. 8 (69\% theme-first vs. $64 \%$ themesecond), $\beta=.16(\mathrm{SE}=.07), z=2.37, p=.02,95 \% \mathrm{CI}[-.001, .30], R^{2}=.51$; Exp. 9 (62\% theme-first vs. $66 \%$ theme-second), $\beta=-.20(\mathrm{SE}=.07), z=-2.93, p=.003,95 \% \mathrm{CI}[-.28,-.04], R^{2}=.53$ (Fig. 2$) .{ }^{10}$

Priming in Exp. 8+replication was significantly greater than priming in Exp. 4+replication (6\% vs. $1 \%)$, (total $\mathrm{N}=944) \beta=-.08(\mathrm{SE}=.03), z=-2.48, p=.01,95 \% \mathrm{CI}[-.15,-.02]$, $R^{2}=.51$, and significantly less than priming in Exp. 7 (6\% vs. 13\%), (total $\left.\mathrm{N}=524\right)$ $\beta=.17(\mathrm{SE}=.07), z=2.28, p=.02,95 \% \mathrm{CI}[.02, .33], R^{2}=.51$.

\footnotetext{
${ }^{10}$ We were unable to compute the profile likelihood confidence intervals on the maximal model for our replication of Exp. 9, so we calculated them instead on a simpler model without the random slopes.
} 


\subsection{Discussion}

In Exps. 8 and 9, we found priming from locatives to datives when the animacy mappings were shared from prime to target. This occurred both when the broad thematic roles were aligned (Exp. 8: animate locative destinations with animate dative recipients, inanimate locative themes with inanimate dative themes) and when they were misaligned (Exp. 9: animate locative themes with animate dative recipients, inanimate locative destinations with inanimate dative themes). Moreover, the effect in Exp. 8 was significantly greater than its closest control (Exp. 4) without the shared animacy mappings. Together, these findings further implicate animacy as an independent contributor to priming from the thematic roles themselves (see also Bock et al., 1992; Gámez \& Vasilyeva, 2015), and additionally suggest that the failure to prime between locatives and datives in Exps. 4 and 5 is due to their thematic differences and not merely the differences in their animacy mappings.

Critically, priming in Exp. 8 was also significantly less than that in Exp. 7. Exps. 7 and 8 are a minimal pair in that they both contain matching animacy features from primes to targets and both cannot be explained by surface syntax. Thus, the most straightforward explanation of these magnitude differences is that thematic structure is additively contributing in Exp. 7 but not in Exp. 8, similar to our Exps. 3 vs. 2 (animacy additively over the thematic roles).

\section{Experiment 10: Reassessing the Priming of Broad Roles}

Our results thus far paint a clear picture of how semantic factors affect priming. Priming occurs both in the face of animacy mismatches from prime to target (Exp. 3) and cross-structurally (Exps. 6 and 7). Yet, priming does not occur between locatives and datives in either direction (Exps. 4 and 5), except for when the priming is plausibly carried by a match in animacy 
mappings from prime to target rather than by the thematic structures themselves (Exps. 8 and 9). Importantly, we see this lack of priming specifically when the thematic roles from prime to target are seemingly distinct (destinations vs. recipients), in line with the narrow roles hypothesis.

As a further test of this claim, we reasoned as follows: Fulfilling verbs prime datives, despite different syntaxes, and both plausibly involve a recipient thematic role, as argued in the Introduction. Indeed, like datives, the non-theme argument in fulfilling verbs is typically an animate entity capable of possession. Locatives and datives do not prime each other, however, which likely reflects a thematic mismatch between the two, in accordance with the narrow roles hypothesis: Locatives have a destination role and datives have a recipient role. Correspondingly, by transitivity, if we use fulfilling verbs to prime locatives, we should expect a similar failure, because the two have distinct thematic structures (and distinct animacy mappings).

\subsection{Materials}

Prime stimuli for Exp. 10 were the same as in Exp. 7. Target stimuli for Exp. 10 were the same as in Exps. 2, 3, and 5.

\subsection{Results}

As predicted, participants in Exp. $10(\mathrm{~N}=172)$ did not produce significantly more theme-first locatives following theme-first fulfilling verbs relative to theme-second fulfilling verbs ( $75 \%$ vs. $75 \%), \beta=.04(\mathrm{SE}=.12), z=.32, p=.75,95 \% \mathrm{CI}[-.26, .31], R^{2}=.43$ (Fig. 2$)$.

Priming in Exp. 10 was significantly less than priming in Exp. 3+replication (0\% vs. $7 \%),($ total $\mathrm{N}=644) \beta=.12(\mathrm{SE}=.05), z=2.43, p=.02,95 \% \mathrm{CI}[.02, .23], R^{2}=.35$, but not 
significantly different from priming in Exp. 5+replication (0\% vs. 4\%), (total N=644)

$\beta=.04(\mathrm{SE}=.05), z=.77, p=.44,95 \% \mathrm{CI}[-.06, .15], R^{2}=.40 .^{11}$

\subsection{Discussion}

We again observe a replicable drop in priming from one construction that plausibly contains a recipient role to another construction that contains a destination role, in favor of the narrow roles hypothesis and against the broad roles hypothesis. Specifically, our minds appear to treat destination and recipient roles as distinct constructs, at least for the purposes of priming, rather than as the single coherent construct of goal.

\section{Experiment 11: Revisiting Bock \& Loebell (1990, Exp. 1)}

Across ten experiments, we found no evidence for priming between constructions that contain a recipient thematic role (e.g., datives, fulfilling verbs) and those that contain a destination role (e.g., locatives), except for when that priming could be carried by animacy alone (Exps. 8 and 9). This suggests that recipients and destinations are distinct, in line with the narrow roles hypothesis, rather than members of a single monolithic category, as argued for by the broad roles hypothesis. Recall, however, that Bock and Loebell (1990, Exp. 1) found equivalent priming of prepositional-object dative targets by motion verb sentences with locative prepositional phrases (e.g., "The wealthy widow drove an old Mercedes to the church") as by other prepositionalobject datives (e.g., "The wealthy widow gave an old Mercedes to the church"). This finding challenges our conclusions. While prepositional-object datives and motion verb sentences have

\footnotetext{
11 We were unable to compute the profile likelihood confidence intervals on the maximal model for the comparison between Exps. 10 and 5+replication, so we calculated them instead on a simpler model without the random slopes.
} 
the same surface syntax (i.e., NP-V-NP-PP), the former have a recipient thematic role while the latter have a destination or location role. Thus, we would have predicted that there would be significantly more priming for the prepositional-object datives (syntax+thematic roles) than for the motion verb sentences (syntax only), given that structural priming is additive, as demonstrated here (e.g., Exps. 1 vs. 7 vs. 8) and elsewhere (e.g., Bernolet et al., 2009, 2014; Gámez \& Vasilyeva, 2015; Griffin \& Weinstein-Tull, 2003; Vernice et al., 2012; Ziegler et al., 2017a).

However, as we noted in the Introduction, some of Bock and Loebell's (1990, Exp. 1) motion verb sentences contained non-alternating dative verbs (e.g., return), which, arguably, have recipient arguments and not destinations. Thus, priming may have been equivalent because the motion verb primes also shared narrow thematic roles with their targets. To verify this intuition, we ran a norming study on Bock and Loebell's (1990, Exp. 1) original prime sentences on Amazon Mechanical Turk. The paper did not contain the full stimulus set, so we were confined to the examples they provided. These included three each of the double-object dative sentences $(3 \mathrm{a}, 4 \mathrm{a}, 5 \mathrm{a})$, the prepositional-object dative sentences $(3 \mathrm{~b}, 4 \mathrm{~b}, 5 \mathrm{~b})$, and the motion verb sentences $(3 c, 4 c, 5 c)$.

(3) a. The wealthy widow sold the church an old Mercedes.

b. The wealthy widow gave an old Mercedes to the church.

c. The wealthy widow drove an old Mercedes to the church.

(4) a. IBM offered the Sears store a bigger computer.

b. IBM promised a bigger computer to the Sears store.

c. IBM moved a bigger computer to the Sears store.

(5) a. The hospital sent the patient the bill by mistake. 
b. The hospital showed the bill to the patient by mistake.

c. The hospital returned the bill to the patient by mistake.

Participants ( $\mathrm{N}=117$; 61 female, 56 male) were asked to rate, for each of 9 sentences, how likely the dative recipient or motion verb location was to now possess the theme, on a 1 to 7 scale ( $1=$ not likely at all, $7=$ very likely). These sentences were interspersed with the motion verb sentences we created for the current work (see below). Strikingly, Bock and Loebell's (1990) motion verb sentences were rated as being equally likely to indicate transfer of possession (4.94[SE=.31]) as their dative sentences (4.99[SE=.20]). Our own motion verb sentences (see below), in contrast, were very unlikely to indicate transfer of possession $(2.39[\mathrm{SE}=.11])$. Thus, we conclude that the absence of a difference in priming in Bock and Loebell (1990) is consistent with the narrow roles hypothesis.

To the best of our knowledge, the only within-language replication of this study was conducted by Potter and Lombardi (1998). ${ }^{12}$ They used motion verbs that do not seem to encode transfer of possession, and they found greater priming for dative primes than for motion verb primes, as we would predict. However, their stimuli were also confounded in another way: The motion verb sentences had inanimate location arguments, while both the dative primes and dative targets had animate recipients. As we have seen in Exps. 8 and 9 (see also Bock et al., 1992; Gámez \& Vasilyeva, 2015), animacy can exert an independent influence in priming. Thus, these results could be due to the cumulative influence of syntactic structure+animacy for the dative primes but only syntax for the motion verb primes.

To verify this interpretation and provide a final test of our hypotheses, we performed a preregistered conceptual replication of Bock and Loebell (1990, Exp. 1). ${ }^{13}$ Specifically, we

\footnotetext{
${ }^{12}$ See fn. 4.

${ }^{13}$ Link to preregistration: https://doi.org/10.17605/OSF.IO/PS7B6.
} 
created motion verb sentences with animate locations that clearly had destination or location roles rather than recipients. The motion verb sentences were constructed by taking the prepositional-object dative prime sentences from our previous experiments (e.g., Exps. 1 and 5) and changing both the verb and the preposition. For example, "The woman threw the ball to the bird" became "The woman raised the ball above the bird." Thus, the prepositional-object datives and motion verbs have the same syntactic phrase structure (i.e., NP-V-PP) and animacy features, but differ in the thematic role assigned to their animate oblique object (see norming results above).

If thematic priming occurs at the level of broad thematic roles (e.g., goal), then we should see no difference in priming between the prepositional-object datives and motion verbs, as in Bock and Loebell (1990). If, on the other hand, the thematic roles are distinct, as our previous results suggest, then we should see more priming for prepositional-object dative primes relative to motion verb primes.

\subsection{Materials}

Prime and target stimuli for Exp. 11 used the following twelve alternating dative verbs (eight old, four new): bring, feed, give, hand, lend, offer, pass, read, sell, send, show, and throw. Prime stimuli for Exp. 11 also used the following twelve non-alternating motion verbs: carry, drag, drop, haul, lift, lower, lug, move, pull, push, raise, and spin.

\subsection{Results}

Participants in Exp. $11(\mathrm{~N}=174)$ produced 73\% prepositional-object descriptions following prepositional-object primes, $62 \%$ prepositional-object descriptions following motion verb 
primes, and $49 \%$ prepositional-object descriptions following double-object primes, suggesting that all three sentence types were treated differently. Accordingly, the full model revealed a significant main effect of Prime Type ( $p s<.001)$, with follow-up pairwise analyses confirming that these effects were driven by double-object dative primes yielding significantly fewer prepositional-object dative productions than either prepositional-object dative primes (49\% vs. $73 \%), \beta=.75(\mathrm{SE}=.09), z=8.41, p<.001,95 \% \mathrm{CI}[.59, .95], R^{2}=.41$, or motion verb primes $(49 \%$ vs. $62 \%), \beta=-.38(\mathrm{SE}=.09), z=-4.14, p<.001,95 \% \mathrm{CI}[-.60,-.19], R^{2}=.42$, consistent with Bock and Loebell (1990). Crucially, however, prepositional-object dative primes also yielded significantly more prepositional-object dative productions than motion verb primes (73\% vs. $62 \%), \beta=.35(\mathrm{SE}=.09), z=4.01, p<.001,95 \% \mathrm{CI}[.15, .53], R^{2}=.45$ (Fig. 2).

\subsection{Discussion}

We do not directly replicate Bock and Loebell's (1990, Exp. 1) original pattern of results. Indeed, although we find significant priming both for datives and motion verbs alike, consistent with this past work, we also find significantly more priming for datives than for motion verbs (see also Potter \& Lombardi, 1998). In Potter and Lombardi (1998), this result was ambiguous: Although priming occurred on the basis of syntax for both sentence types, the decreased priming they observed for their transitive sentences with locative prepositional phrases relative to prepositional-object datives could have been due either to the narrow thematic roles not matching up from prime to target (and therefore not boosting priming) or to animacy (which was not shared between prime and target for their transitive sentences but was for their prepositionalobject dative sentences). In contrast, our results are straightforwardly consistent with participants having treated the thematic roles of these two sets of constructions as distinct: Participants were 
primed by both sentence types on the basis of syntax but significantly more so for prepositionalobject datives, which share a narrow thematic role with the prepositional-object dative targets, than for motion verb sentences, which do not share a narrow role with the prepositional-object dative targets. Crucially, this difference cannot be due to differences in animacy (as in Potter \& Lombardi, 1998), since both our motion verb sentences and prepositional-object datives had animate prepositional arguments and inanimate themes (and therefore cannot be the reason why the latter led to more priming than the former). This is the pattern of results expected on the narrow roles hypothesis, which our previous experiments have also supported, but not on the broad roles hypothesis.

\section{General Discussion}

These experiments investigated the scope of structural priming, using it as a tool to explore the grain size of the thematic mappings that guide language production. Specifically, we were interested in whether destination and recipient thematic roles can be subsumed under a single role, goal, in line with the broad roles hypothesis (e.g., Anderson, 1971; Baker, 1996; Harley, 2003; Goldberg, 1995, 2002, 2006; Gruber, 1965; Lakoff \& Johnson, 1980; Jackendoff, 1972, 1983; Pylkkänen, 2008), or whether the language processing system treats the two as distinct, consistent with the narrow roles hypothesis (e.g., Bresnan \& Kanerva, 1989; Pinker, 1989; Rappaport Hovav \& Levin, 2008). Our overall pattern of results speaks against the broad roles hypothesis: We did not find priming between recipients and destinations across distinct constructions, except for when plausibly carried by animacy and/or syntax. For example, there was no priming between locatives and datives (Exps. 4 and 5) or between locatives and fulfilling verbs (Exp. 10) when the datives and fulfilling verbs had animate recipients and the locatives had 
inanimate destinations. However, we did find priming from locatives to datives when there was an animacy distinction in the locative primes that could influence animacy ordering in the dative targets (Exps. 8 and 9). In addition, we found significantly greater priming between dative primes and dative targets than between motion verb primes and dative targets (Exp. 11), where the key difference was in the composition of their thematic roles (recipients for datives, destinations for motion verbs). Our results therefore support the narrow roles hypothesis, in which destinations and recipients are distinct.

Importantly, our results cannot be reduced to priming on the basis of animacy alone. First, in some cases, animacy cannot have contributed at all (e.g., Exps. 2-5 and 10). We found robust priming among locatives when neither animacy nor syntax provided any clues as to the relative ordering of the post-verbal arguments (Exps. 2 and 3), confirming that purely thematic priming is possible. Second, animacy cannot explain the differences in the magnitude of priming we observed among Exps. 1, 7, and 8 or within Exp. 11. Specifically, we found significantly less priming in Exp. 7 than in Exp. 1 and significantly more priming in Exp. 7 than in Exp. 8. Since the configuration of animate and inanimate arguments in all three cases was the same, animacy cannot account for these differences. Instead, the reason we see the most priming among datives (Exp. 1) is because animacy, syntax, and thematic role ordering are all contributing; the reason we see intermediate priming from fulfilling verbs to datives (Exp. 7) is because both animacy and thematic role ordering (but not syntax) are contributing; and the reason we see the least priming from locatives with animate destinations to datives (Exp. 8) is because only animacy (but neither syntax nor thematic role ordering) is contributing (see Table 1). Similarly, we found significantly less priming between motion verb sentences with locative prepositional phrases and datives than between datives and other datives (Exp. 11) precisely because only animacy and 
syntax contributed to the former, while animacy, syntax, and thematic role ordering all contributed to the latter (see Table 1).

Nevertheless, although not reducible to animacy, these results broaden our understanding of the contribution of animacy to structural priming in important ways. For example, we found priming between locatives and datives only when there was an animacy distinction in the locative primes that could influence animacy ordering in the dative targets (Exps. 8 and 9). This occurred both when the thematic roles were broadly aligned (locative themes with dative themes, locative destinations with dative recipients) and when they were not (locative themes with dative recipients, locative destinations with dative themes). These results confirm that animacy is an independent contributor to priming separate from the influences of either thematic roles or syntax (see also Bock, Loebell, \& Morey, 1992; Gámez \& Vasilyeva, 2015) and extend animacy priming to a new pair of constructions (locatives and datives).

In the remainder of this discussion, we consider, in turn, (1) the influence of syntax on priming, (2) how current models of priming might account for these results, (3) what the representations underlying thematic priming are likely to be, (4) whether our results speak to a further subdivision of dative verbs, (5) the role of animacy in argument realization, and (6) how to reconcile the centrality of the notion of goal in human cognition with the present results.

\subsection{Independent influence of syntax on structural priming}

Everyone agrees that syntax can be primed (e.g., Branigan, 2007; Branigan \& Pickering, 2017; Mahowald et al., 2016; Pickering \& Ferreira, 2008; Tooley \& Traxler, 2010). We contribute to this consensus additional evidence for the role of syntax as an independent source of priming. Recall that we found no differences in priming between locatives and datives on the basis of 
thematic structure (Exps. 4 and 5). However, locatives as a class only share the same surface phrase structure with prepositional-object datives (NP-V-NP-PP) and not double-object datives (NP-V-NP-NP). This leaves open the possibility that both locative types may have led to an increase in prepositional-object dative productions relative to double-object dative primes, on the basis of shared syntax with the former but not the latter. To test this prediction, we conducted a follow-up analysis combining Exps. 1 and 4 (same dative targets) in a separate logistic mixedeffects model (N=224), with Prime Type (Prepositional-object Dative, Double-object Dative, Locative) as an effect-coded $(1,-1)$ fixed effect and the same maximal random effects structure as before. The model revealed a significant main effect of Prime Type ( $p s<.002)$, with follow-up pairwise analyses confirming a significant difference between locatives and double-object datives $(67 \%$ vs. $44 \%), \beta=-.85(\mathrm{SE}=.19), z=-4.49, p<.001$, but not between locatives and prepositional-object datives $(67 \%$ vs. $74 \%), \beta=-.03(\mathrm{SE}=.17), z=-.16, p=.87$. Thus, participants appear to have treated locatives and prepositional-object datives similarly, consistent with priming at the level of syntax (independently of thematic roles and animacy).

\subsection{Implications for models of priming}

Models that instantiate structural priming as implicit learning have gained a lot of traction in recent years (e.g., Branigan \& McLean, 2016; Chang et al., 2006; Jaeger \& Snider, 2013; Reitter, Keller, \& Moore, 2011). One such model, Chang et al.'s (2006) Dual-Path Model, makes explicit use of thematic role information and offers an interesting perspective on the present findings. The Dual-Path Model is a model of sentence production. It uses supervised learning to link sentence forms to messages, and then is tested on how well it creates an accurate grammatical surface structure for a new message. To simulate priming, the model is exposed to a prime 
sentence word-by-word, adjusts its message-to-sentence weights on the basis of how well it predicted each subsequent word in the sentence, and then uses these adjusted weights to produce a new target sentence from an event representation. If the target sentence matches the structure of the prime, it counts as priming, otherwise it does not.

The Dual-Path Model has the ability to learn two types of syntactic representations: purely structural representations (syntactic phrase structure) and structural representations imbued with meaning (thematic roles) (Chang et al., 2006). Which representation is learned varies across constructions, though syntax is privileged. Specifically, if the model can distinguish two variants of an alternation on the basis of phrase structure alone, as in the case of the dative alternation, it learns a purely syntactic representation: NP-V-NP-NP vs. NP-V-NP-P-NP. If syntax alone does not differentiate them, as in the case of the locative alternation, then the model learns a syntactic representation supplemented with broad thematic roles: AGENT-V-THEMEP-GOAL vs. AGENT-V-GOAL-WITH-THEME.

Given that the representations learned by the model for these two sets of constructions are different, Chang et al.'s (2006) model correctly predicts that locatives will not prime datives (Exp. 4) and datives will not prime locatives (Exp. 5). Furthermore, the authors found that the model exhibited priming from motion verbs with locative prepositional phrases to prepositionalobject datives (p. 249), consistent with our significant difference in Exp. 11 between motion verbs and double-object datives (also Bock \& Loebell, 1990; Potter \& Lombardi, 1998). Elsewhere (pp. 250-251), Chang et al. (2006) tried a version of the model with thematic roles that are similar to our narrow roles hypothesis and again found significant motion-verb-to-dative priming. However, they also found that the magnitude of this priming was reduced by using these narrow roles, which is consistent with the significant difference between motion verbs and 
prepositional-object datives we observed in Exp. 11 (also Potter \& Lombardi, 1998). Further work is needed to see whether this model could explain the full range of data in this paper, although we suspect that narrow roles will also be needed to capture the priming pattern of fulfilling verbs (Exps. 7 and 10).

\subsection{Role of animacy in argument realization}

Our findings also bear on questions about the relationship between thematic roles and the animacy of the arguments that fill those roles. Many thematic roles are typically animate (e.g., agent, recipient, experiencer) or inanimate (e.g., patient, theme). Thus, it is tempting to assume that animacy affects syntactic argument realization solely via thematic role selection. Our results are inconsistent with this assumption. To understand this more fully, we have to consider two hypotheses about how animacy might influence priming.

On the hypothesis where animacy solely affects role selection, we would have to posit an underspecified broad goal role that becomes a recipient by virtue of the animacy of the filler noun that takes that role. If that were the case, we expect that changing the animacy of the filler of the non-theme role in the locatives should have created a recipient rather than destination, thereby also yielding equivalent priming between locatives with animate destinations and datives (Exp. 8) as that between fulfilling verbs and datives (Exp. 7). This hypothesis can in no way account for the priming we saw in Exp. 9, however, in which theme-first locatives with animate themes resulted in more double-object over prepositional-object dative responses. To do so, we would have to posit themes as also changing to recipients by virtue of the animacy of their fillers.

Thus, our results lead us to a second hypothesis, in which both thematic roles and the links between animacy features and syntactic positions can be primed independently of one 
another. On this hypothesis, there are cases of pure thematic priming (e.g., Exp. 2), which cannot be explained by any other factors. There are also cases where priming is mediated solely by mappings between animacy and syntactic position (e.g., Exp. 9). This hypothesis is fully consistent with our results.

What this hypothesis fails to explain is why particular thematic roles seem to require, or at least strongly prefer, animate fillers. For instance, I cannot send New York the package, unless New York is meant to refer to something like the New York office rather than the place (Goldberg, 1995; Pesetsky, 1995; Pinker, 1989; Rappaport Hovav \& Levin, 2008). While our data clearly show independence of thematic roles and animacy, they leave open several means of accounting for these tendencies. First, some but not all roles could place restrictions on their contents. Experiencers, for instance, are probably always animate. Likewise, recipients, though not always animate, do strongly prefer to be (though cf. examples like "give the house a coat of paint"; Rappaport Hovav \& Levin, 2008, fn. 10; see also McIntyre, 2006). Second, animacy in these cases could be an inference rather than a restriction. Particular verbs (e.g., give) or particular sub-predicates in the thematic structure (e.g., CAUSE, HAVE) could imply things about their arguments that are only true of animate entities. Critically, whatever the explanation for these animacy requirements is, it cannot account for our priming between animacy and syntactic positions independent of thematic roles (Exp. 9).

The animacy priming we observed provides evidence that the features of filler nouns can play an independent role in syntactic argument realization. This is challenging for theories in which argument realization depends entirely upon thematic roles (or predicate decompositions; for discussion, see Levin \& Rappaport Hovav, 2005). While it is not clear how to integrate these independent animacy mappings into our theory of argument realization (though for competing 
accounts see Branigan, Pickering, \& Tanaka, 2008; Chang, 2009), this is not the first or only piece of evidence that suggests such a step will be necessary. For example, Irish allows only animate entities to be subjects (Guilfoyle, 1995, 2000; for discussion, see Levin \& Rappaport Hovav, 2005). In other cases, animacy has probabilistic effects. In the dative alternation, for instance, animate recipients typically favor the double-object construction, while inanimate recipients typically favor the prepositional-object construction (Bresnan, Cueni, Nikitina, \& Baayen, 2007; Bresnan \& Nikitina, 2009; Collins, 1995; Evans, 1997; Gries, 2003; Thompson, 1990). Ultimately, our theory of argument realization will need to account for both types of influences (thematic roles and animacy) in order to capture the entire range of findings to date.

\subsection{Sub-dividing dative verbs}

Throughout this paper, we have treated alternating dative verbs as a monolithic class. Many theorists, however, have pointed out that there are systematic differences between different subclasses of datives (e.g., Jackendoff, 1990; Rappaport Hovav \& Levin, 2008). For example, Rappaport Hovav and Levin (2008) argue for a three-way distinction among give-type verbs, send-type verbs, and throw-type verbs. They propose that all three subclasses are consistent with a transfer of possession meaning. However, the send-and throw-type verbs in the prepositionalobject variant are also consistent with a caused motion meaning, while the give-type verbs are not. If we translate this hypothesis into thematic role terminology, it implies that while give-type datives always have a recipient, send-and throw-type datives can have either a recipient or a destination.

This proposal adds a possible wrinkle to the interpretation of our findings. We have assumed that all of the dative sentences we constructed for these experiments had a recipient role 
in both the double-object and prepositional-object constructions. If they had destinations or locations, it is unclear how we could account for the observed priming patterns. To explore this possibility, we did three things. First, we classified our verbs based on the verb classes described in Rappaport Hovav and Levin (2008). We discovered that nine of our verbs are give-type verbs (i.e., feed, give, hand, lend, offer, pass, read, sell, and show), which are expected to have recipients in all cases. Three of our verbs, however, were send- or throw-type verbs (i.e., bring, send, and throw), which could potentially have a destination role.

Second, we tested whether participants interpreted our stimulus sentences as having recipients in a norming study on Amazon Mechanical Turk that was identical in structure to the one we performed for Exp. 11. Participants ( $\mathrm{N}=118 ; 59$ female, 57 male, 2 other) were asked to rate, for each of 9 dative sentences, how likely the recipient was to now possess the theme, on a 1 to 7 scale ( $1=$ not likely at all, $7=$ very likely). The prepositional-object variants of bring, send, and throw were rated as being equally likely to indicate transfer of possession $(4.65[\mathrm{SE}=.23])$ as their double-object counterparts (4.57[SE=.24]); crucially, no differences were observed between these sentences and the prepositional-object and double-object variants of the give-type verbs (prepositional-object: 4.73[SE=.15]; double-object: 4.69[SE=.14]), all $p s>.85 .{ }^{14}$ Thus, all our dative sentences seem to have recipient thematic roles.

Finally, we conducted a follow-up analysis on the combined results of Exps. 4 and 8 (locative-to-dative priming), to see whether priming between locatives and send-/throw-type datives might have been greater than that between locatives and give-type datives. If so, this

\footnotetext{
${ }^{14}$ For this analysis, we entered Prime Type (Prepositional-object vs. Double-object), Verb Type (Give vs. Send/Throw), and their interaction as fixed effects into a linear mixed-effects model (lme4 package) in R, with random intercepts for participant and item (verb) and random slopes for Prime Type within both participants and items. Neither the main effects for Prime Type, $\beta=-.01(\mathrm{SE}=.07), t=-.18, p=.86$, and Verb Type, $\beta=.06(\mathrm{SE}=.44)$, $t=.14, p=.89$, nor the interaction was significant, $\beta=.01(\mathrm{SE}=.08), t=.10, p=.92$.
} 
would be evidence that our send-and throw-type dative sentences included at least some destination roles. ${ }^{15}$ We found no evidence for differential priming (interaction) by dative subtype (Give: $6 \%$ priming; Send/Throw: $4 \%$ priming), (total $\mathrm{N}=944) \beta=.01(\mathrm{SE}=.08), z=.07, p=.94 .{ }^{16}$

While it is clear from the experiments in this paper that our dative sentences with recipient roles did not prime locative sentences with destination roles, we cannot determine from these data whether there are dative sentences with destination roles and whether such datives would prime locative sentences (or vice versa). Clearly, the theory presented in this paper predicts that if such sentences exist, and if animacy is controlled, then priming of this type should occur.

\section{5. “Goals” in linguistics and cognitive development}

The term "goal" is used widely both in research on linguistic representation (e.g., Goldberg, 1995; Harley, 2003; Levin \& Rappaport Hovav, 2005; Jackendoff, 1990) and in research on prelinguistic cognitive development (e.g., Hamlin, 2015; Liu, Ullman, Tenenbaum, \& Spelke, 2017; Woodward, 1998). This raises the question of how the respective notions relate to each other, if at all. We see three broad possibilities consistent with the present findings.

One possibility is that (a) there is a single domain-general representation of events which the pre-linguistic infant studies are tapping into, and which will ultimately come to guide semantic encoding for language production in adults, and (b) this domain general system represents a single broad role of goal. If this is the case, what our data suggest is that the adult

\footnotetext{
${ }^{15} \mathrm{We}$ could not look in the opposite direction (dative-to-locative priming), however, due to the nature of our trial structure (i.e., two primes for every target), because send- and throw-type datives were frequently paired with givetype datives as priming doublets in the relevant experiment (Exp. 5).

${ }^{16}$ This analysis included Prime Type (Prepositional-object vs. Double-object), Verb Type (Give vs. Send/Throw), and their interaction as fixed effects in a logistic mixed-effects model (lme4 package) in R, with random intercepts for participant and item (verb) and random slopes for Prime Type within both participants and items.
} 
linguistic system also has notions of recipient and destination, that are perhaps subcategories of goals, and it is these narrower notions that contribute to priming. The question then becomes: Where do these narrower roles come from? Are they constructed in the course of language acquisition? Or are they part of our innate linguistic endowment?

A second possibility is that there is a single domain-general system for event representation, but that this system represents recipients and destinations as separate discrete roles. To the best of our knowledge, there are no studies in the infant event perception literature which show that babies treat recipients and destinations as a single construct. There are experiments showing that infants represent possession, or at least desire (e.g., Woodward, 1998), and there are experiments showing that they encode destinations (e.g., Lakusta, Spinelli, \& Garcia, 2017). But we know of no work that shows that they generalize across these constructs. Until such evidence is available, it is plausible that this broad notion of goal that is available to theorists is not available either to infants or to the language production system.

A third and final possibility is that there are two separate domain-specific systems for event representation: one which guides infants' analysis of action and another which guides argument realization in language production. On this hypothesis, the existence of a broad notion of goal in early action understanding has no bearing on the question of whether there is a broad notion of goal in the linguistic system. This may seem counterintuitive; after all, both literatures use the word goal. However, what the word goal refers to in each case seems very different. The term goal in the pre-linguistic infant literature typically refers to the mental objects of intention or desire (for reviews, see Spelke \& Kinzler, 2007; Woodward, 2009). In contrast, goal in the linguistics literature refers to an entity that is the endpoint of an action, either the destination in a motion event or the recipient in a transfer-of-possession event. Thus, while the toy bear that the 
hand reaches for in Woodward's (1998) classic study is called a goal, most linguists would consider it to be a theme or a patient.

Cross-cutting these issues of domain-specificity is the question of whether narrower and broader roles can coexist within the linguistic system. Such coexistence would be consistent with the semantic architectures proposed by Dowty $(1989,1991)$ and within the tradition of Role and Reference Grammar (e.g., Van Valin \& LaPolla, 1997). For example, Van Valin and LaPolla (1997) propose two relevant levels of thematic role representation. On the one hand, there are the traditional thematic roles like agent, recipient, theme, and destination. On the other hand, there is also a level of representation that captures generalizations across these traditional roles, known as macroroles. Dowty $(1989,1991)$ also proposes a hierarchy of narrow (verb-specific) and midsized (agent- and patient-level) roles, in addition to even broader prototype notions (i.e., protoroles) that serve a similar function as macroroles. With respect to this question, what our data suggest is that this broader level of representation, if it exists, isn't involved in priming.

Another approach that invokes multiple kinds of roles is one in which narrower roles are subsumed in broader roles. Several researchers have noted, for instance, that the set of events that can be described with double-object syntax (e.g., double-object datives), which necessarily entails a recipient role, are a subset of those events that can be described with prepositionalobject syntax (e.g., prepositional-object datives, theme-first locatives), entailing either a recipient role or a destination role (e.g., Beavers, 2011; Pesetsky, 1995; Rappaport Hovav \& Levin, 2008; though cf. Harley, 2005). On this type of approach, goal would refer to the endpoint (spatial or metaphorical) of an action, and recipient would refer to a specific type of endpoint (specified for possession). Recipients would inherit both the meaning and form of the broader notion of goal. But the goal role would inherit nothing from the narrower specification of recipient. This theory 
makes the prediction that recipients will prime goals (i.e., dative-to-locative priming in Exp. 5), but that goals will not necessarily prime recipients (i.e., locative-to-dative priming in Exp. 4; for similar subsumption arguments regarding benefactives and datives, see, e.g., Goldberg, 1995; Pappert \& Pechmann, 2013). We found no evidence for unidirectional priming of this sort, and thus, this relationship, if it exists, is not manifest in priming.

\section{Conclusion}

We found no evidence that speakers treat the recipient role in dative or fulfilling verb sentences as equivalent to the destination role in locative or motion verb sentences. These results speak against the broad roles hypothesis, which states that the thematic roles destination and recipient form a broad class, goal, and instead are more in line with the narrow roles hypothesis, in which destinations and recipients are distinct. We also observed an independent influence of animacy on priming in the absence of thematic role overlap. Our findings are consistent with a picture of conceptual and semantic representation in which thematic structure and animacy comprise distinct constraints on argument realization. The complexity of these results challenges our desire for a parsimonious theory in which structural priming is solely syntactic (see also Ziegler, Snedeker, \& Wittenberg, 2017b). A full theory of the mental architecture of language production requires that we account for (at least) syntactic-, thematic-, and animacy-based priming. 


\section{Acknowledgments}

This research was funded in part by a Norman Henry Anderson Graduate Psychology Fund grant from Harvard GSAS to JZ. Special thanks to Steven Pinker, the members of SnedLab/Harvard LDS/Harvard Psychology, and audiences at Harvard's Cognition, Brain, \& Behavior Research Seminar, UCSD's Center for Research in Language, MIT's Language Lab (TedLab), CUNY 2016, and CogSci 2016 for helpful feedback and discussion; to Brianne Gallagher and especially Anthony Yacovone for stim creation and norming; and to Miriam Hauptman, Jared Hawn, and Sarah Raulston for assistance with coding. 


\section{References}

Anderson, J. M. (1971). The grammar of case. Cambridge, UK: Cambridge University Press.

Baayen, R. H., Davidson, D. J., \& Bates, D. M. (2008). Mixed-effects modeling with crossed random effects for subjects and items. Journal of Memory and Language, 59(4), 390-412.

Baker, M. C. (1988). Incorporation: A theory of grammatical function changing. Chicago, IL: University of Chicago Press.

Baker, M. C. (1996). On the structural positions of themes and goals. In J. Rooryck \& L. Zaring (Eds.), Phrase Structure and the Lexicon (pp. 7-34). Dordrecht: Springer.

Barr, D. J., Levy, R., Scheepers, C., \& Tily, H. J. (2013). Random effects structure for confirmatory hypothesis testing: Keep it maximal. Journal of Memory and Language, 68(3), 255-278. doi:10.1016/j.jml.2012.11.001

Bates, D. M. (2010). lme4: Mixed-effects modeling with R. Available online at http://lme4.rforge.r-project.org/book/.

Beavers, J. (2011). An aspectual analysis of ditransitive verbs of caused possession in English. Journal of Semantics, 28, 1-54.

Bernolet, S., Colleman, T., \& Hartsuiker, R. J. (2014). The "sense boost" to dative priming: Evidence for sense-specific verb-structure links. Journal of Memory and Language, 76, 113-126.

Bernolet, S., Hartsuiker, R. J., \& Pickering, M. J. (2009). Persistence of emphasis in language production: A cross-linguistic approach. Cognition, 112, 300-317.

Bock, J. K. (1986). Syntactic persistence in language production. Cognitive Psychology, 18, 355387.

Bock, K. (1989). Closed-class immanence in sentence production. Cognition, 31, 163-186. 
Bock, K., \& Loebell, H. (1990). Framing sentences. Cognition, 35, 1-39.

Bock, K., Loebell, H., \& Morey, R. (1992). From conceptual roles to structural relations:

Bridging the syntactic cleft. Psychological Review, 99, 150-171.

Branigan, H. P. (2007). Syntactic priming. Language and Linguistics Compass, 1(1-2), 1-16.

Branigan, H. P., \& McLean, J. F. (2016). What children learn from adults' utterances: An ephemeral lexical boost and persistent syntactic priming in adult-child dialogue. Journal of Memory and Language, 91, 141-157.

Branigan, H. P., \& Pickering, M. J. (2017). An experimental approach to linguistic representation. Behavioral and Brain Sciences, 40, e282.

Branigan, H. P., Pickering, M. J., Liversedge, S. P., Stewart, A. J., \& Urbach, T. P. (1995). Syntactic priming: Investigating the mental representation of language. Journal of Psycholinguistic Research, 24(6), 489-506.

Branigan, H. P., Pickering, M. J., \& Tanaka, M. (2008). Contributions of animacy to grammatical function assignment and word order during production. Lingua, 118(2), 172189.

Bresnan, J., \& Kanerva, J. (1989). Locative inversion in Chicheŵa: A case study of factorization in grammar. Linguistic Inquiry, 20(1), 1-50.

Bresnan, J., \& Nikitina, T. (2009). The gradience of the dative alternation. In L. Uyechi \& L.-H. Wee (Eds.), Reality and Exploration: Pattern Interaction in Language and Life (pp. 161184). Stanford: CSLI Publications.

Bresnan, J., Cueni, A., Nikitina, T., \& Baayen, H. (2007). Predicting the dative alternation. In G. Boume, I. Kraemer, \& J. Zwarts (Eds.), Cognitive Foundations of Interpretation (pp. 6994). Amsterdam: Royal Netherlands Academy of Science. 
Cai, Z. G., Pickering, M. J., \& Branigan, H. P. (2012). Mapping concepts to syntax: Evidence from structural priming in Mandarin Chinese. Journal of Memory and Language, 66(4), 833-849.

Carminati, M. N., van Gompel, R. P. G., Scheepers, C., \& Arai, M. (2008). Syntactic priming in comprehension: The role of argument order and animacy. Journal of Experimental Psychology: Learning, Memory, and Cognition, 34(5), 1098-1110.

Chang, F. (2009). Learning to order words: A connectionist model of heavy NP shift and accessibility effects in Japanese and English. Journal of Memory and Language, 61, 374397.

Chang, F., Bock, K., \& Goldberg, A. E. (2003). Can thematic roles leave traces of their places? Cognition, 90, 29-49.

Chang, F., Dell, G. S., \& Bock, K. (2006). Becoming syntactic. Psychological Review, 113(2), $234-272$.

Chierchia, G. (1998). Plurality of mass nouns and the notion of "semantic parameter." Events and Grammar, 70, 53-103.

Cho-Reyes, S., Mack, J. E., \& Thompson, C. K. (2016). Grammatical encoding and learning in agrammatic aphasia: Evidence from structural priming. Journal of Memory and Language, 91, 202-218.

Collins, P. (1995). The indirect object construction in English: An informational approach. Linguistics, 33, 35-49.

Dowty, D. R. (1989). On the semantic content of the notion "thematic role." In G. Chierchia, B. H. Partee, \& R. Turner (Eds.), Properties, Types, and Meaning (pp. 69-129). Dordrecht: Kluwer.

Dowty, D. R. (1991). Thematic proto-roles and argument selection. Language, 67(3), 547-619. 
Evans, N. (1997). Role or cast? Noun incorporation and complex predicates in Mayali. In A.

Alsina, J. Bresnan, \& P. Sells (Eds.), Complex Predicates (pp. 397-430). Stanford: CSLI Publications.

Fillmore, C. J. (1968). The case for Case. In E. Bach \& R. T. Harms (Eds.), Universals in Linguistic Theory (pp. 1-88). New York: Holt, Rinehart, and Winston.

Fisher, C., Gleitman, L., \& Gleitman, H. (1991). On the semantic content of subcategorization frames. Cognitive Psychology, 23, 331-392.

Gámez, P. B., \& Vasilyeva, M. (2015). Exploring interactions between semantic and syntactic processes: The role of animacy in syntactic priming. Journal of Experimental Child Psychology, 138, 15-30.

Goldberg, A. E. (1995). Constructions: A construction grammar approach to argument structure. Chicago, IL: University of Chicago Press.

Goldberg, A. E. (2002). Surface generalizations: An alternative to alternations. Cognitive Linguistics, 13(4), 327-356.

Goldberg, A. E. (2006). Constructions at work: The nature of generalization in language. Oxford: Oxford University Press.

Gries, S. T. (2003). Towards a corpus-based identification of prototypical instances of constructions. Annual Review of Cognitive Linguistics, 1, 1-28.

Griffin, Z. M., \& Weinstein-Tull, J. (2003). Conceptual structure modulates structural priming in the production of complex sentences. Journal of Memory and Language, 49, 537-555.

Gruber, J. (1965). Studies in lexical relations (Doctoral dissertation). MIT, Cambridge, MA.

Guilfoyle, E. (1995). The acquisition of Irish and the internal structural of VP in early child grammars. In A. Stringfellow, D. Cahana-Amitay, E. Hughes, \& A. Zukowski (Eds.), 
Proceedings of the 20th Annual Boston University Conference on Language Development (pp. 296-307). Somerville, MA: Cascadilla Press.

Guilfoyle, E. (2000). Tense and N-features in Modern Irish. In A. Carnie \& E. Guilfoyle (Eds.), The Syntax of Verb Initial Languages (pp. 61-73). Oxford: Oxford University Press.

Gureckis, T. M., Martin, J., McDonnell, J., Rich, A. S., Markant, D., Coenen, A., . . Chan, P. (2016). psiTurk: An open-source framework for conducting replicable behavioral experiments online. Behavioral Research Methods, 48(3), 829-842. doi:10.3758/s13428015-0642-8

Hamlin, J. K. (2015). The case for social evaluation in preverbal infants: Gazing towards one's goal drives infants' preferences for Helpers over Hinderers in the hill paradigm. Frontiers in Psychology, 5, 1563.

Hare, M. L., \& Goldberg, A. E. (1999). Structural priming: Purely syntactic? In M. Hahn \& S. C. Stones (Eds.), Proceedings of the 21st Annual Meeting of the Cognitive Science Society (pp. 208-211). Mahwah, NJ: Erlbaum.

Harley, H. (2003). Possession and the double object construction. In P. Pica (Ed.), Linguistic Variation Yearbook (Vol. 2, pp. 31-70). Amsterdam: John Benjamins.

Harley, H. (2005). How do verbs get their names? Denominal verbs, manner incorporation, and the ontology of verb roots in English. In N. Erteschik-Shir \& T. Rapoport (Eds.), The Syntax of Aspect: Deriving Thematic and Aspectual Interpretation (pp. 42-64). Oxford, UK: Oxford University Press.

Huang, J., Pickering, M. J., Yang, J., Wang, S., \& Branigan, H. P. (2016). The independence of syntactic processing in Mandarin: Evidence from structural priming. Journal of Memory and Language, 91, 81-98. 
Jackendoff, R. S. (1972). Semantic interpretation in generative grammar. Cambridge, MA: MIT Press.

Jackendoff, R. S. (1983). Semantics and cognition. Cambridge, MA: MIT Press.

Jackendoff, R. S. (1990). Semantic structures. Cambridge, MA: MIT Press.

Jaeger, T. F. (2008). Categorical data analysis: Away from ANOVAs (transformation or not) and towards logit mixed models. Journal of Memory and Language, 59(4), 434-446.

Jaeger, T. F., \& Snider, N. E. (2013). Alignment as a consequence of expectation adaptation: Syntactic priming is affected by the prime's prediction error given both prior and recent experience. Cognition, 127, 57-83.

Köhne, J., Pickering, M. J., \& Branigan, H. P. (2014). The relationship between sentence meaning and word order: Evidence from structural priming in German. The Quarterly Journal of Experimental Psychology, 67(2), 304-318.

Lakoff, G., \& Johnson, M. (1980). Metaphors we live by. Chicago: The University of Chicago Press.

Lakusta, L., Spinelli, D., \& Garcia, K. (2017). The relationship between pre-verbal event representations and semantic structures: The case of goal and source paths. Cognition, 164, 174-187.

Levin, B. (1993). English verb classes and alternations: A preliminary investigation. Chicago, IL: University of Chicago Press.

Levin, B., \& Rappaport Hovav, M. (2005). Argument realization. Cambridge: Cambridge University Press.

Liu, S., Ullman, T. D., Tenenbaum, J. B., \& Spelke, E. S. (2017). Ten-month-old infants infer the value of goals from the costs of actions. Science, 358(6366), 1038-1041. 
Mahowald, K., James, A., Futrell, R., \& Gibson, E. (2016). A meta-analysis of syntactic priming in language production. Journal of Memory and Language, 91, 5-27. http://dx.doi.org/10.1016/j.jml.2016.03.009

McIntyre, A. (2006). The interpretation of German datives and English have. In D. Hole, A. Meinunger, \& W. Abraham (Eds.), Datives and Other Cases: Between Argument Structure and Event Structure (pp. 185-211). Amsterdam: John Benjamins.

Pappert, S., \& Pechmann, T. (2013). Bidirectional structural priming across alternations: Evidence from the generation of dative and benefactive alternation structures in German. Language and Cognitive Processes, 28, 1303-1322.

Pappert, S., \& Pechmann, T. (2014). Priming word order by thematic roles: No evidence for an additional involvement of phrase structure. The Quarterly Journal of Experimental Psychology, 67(11), 2260-2278.

Pesetsky, D. (1995). Zero syntax. Cambridge, MA: MIT Press.

Pickering, M. J., \& Branigan, H. P. (1998). The representation of verbs: Evidence from syntactic priming in language production. Journal of Memory and Language, 39, 633-651.

Pickering, M. J., \& Ferreira, V. S. (2008). Structural priming: A critical review. Psychological Bulletin, 134(3), 427-459.

Pinker, S. (1989). Learnability and cognition: The acquisition of argument structure. Cambridge, MA: MIT Press.

Potter, M. C., \& Lombardi, L. (1998). Syntactic priming in immediate recall of sentences. Journal of Memory and Language, 38(3), 265-282.

Pylkkänen, L. (2008). Introducing arguments. Cambridge, MA: MIT Press. 
Rappaport Hovav, M., \& Levin, B. (2008). The English dative alternation: The case for verb sensitivity. Journal of Linguistics, 44(1), 129-167.

Reitter, D., Keller, F., \& Moore, J. D. (2011). A computational cognitive model of syntactic priming. Cognitive Science, 35, 587-637.

Salamoura, A, \& Williams, J. N. (2007). Processing verb argument structure across languages: Evidence for shared representations in the bilingual lexicon. Applied Psycholinguistics, $28,627-660$.

Scheepers, C., Raffray, C. N., \& Myachykov, A. (2017). The lexical boost effect is not diagnostic of lexically-specific syntactic representations. Journal of Memory and Language, 95, 102-115.

Spelke, E. S., \& Kinzler, K. D. (2007). Core knowledge. Developmental Science, 10, 89-96.

Thompson, S. (1990). Information flow and dative shift in English discourse. In J. A.

Edmondson, F. Crawford, \& P. Mühlhäusler (Eds.), Development and Diversity: Language Variation across Space and Time (pp. 239-253). Dallas, TX: Summer Institute of Linguistics.

Tooley, K. M., \& Traxler, M. J. (2010). Syntactic priming effects in comprehension: A critical review. Language and Linguistics Compass, 4(10), 925-937.

Van Valin, Jr., R. D., \& LaPolla, R. J., (1997). Syntax: Structure, meaning, and function. Cambridge, UK: Cambridge University Press.

Vernice, M., Pickering, M. J., \& Hartsuiker, R. J. (2012). Thematic emphasis in language production. Language and Cognitive Processes, 27(5), 631-664.

Woodward, A. L. (1998). Infants selectively encode the goal object of an actor's reach. Cognition, 69, 1-34. 
Woodward, A. L. (2009). Infants' grasp of others' intentions. Current Directions in Psychological Science, 18(1), 53-57.

Yi, E., \& Koenig, J.-P. (2016). Why verb meaning matters to syntax. In J. Fleischhauer, A. Latrouite, \& R. Osswald (Eds.), Explorations of the Syntax-Semantics Interface (pp. 5776). Düsseldorf: Düsseldorf University Press.

Ziegler, J., Snedeker, J., \& Wittenberg, E. (2017a). Different paths from structure to event construal in idiomatic, semi-idiomatic, and fully transparent expressions. Poster presented at the 30th Annual Meeting of the CUNY Conference on Human Sentence Processing, Cambridge, MA.

Ziegler, J., Snedeker, J., \& Wittenberg, E. (2017b). Priming is swell, but it's far from simple (commentary on Branigan \& Pickering’s “An experimental approach to linguistic representation"). Behavioral and Brain Sciences, 40, 44-45. 
Appendix A. Prime sentences by experiment.

\begin{tabular}{|c|c|c|c|}
\hline \multicolumn{3}{|c|}{ Datives } & \multirow{2}{*}{$\begin{array}{l}\text { Motion verbs (Exp. } \\
11 \text { only) }\end{array}$} \\
\hline Exp. & Double-object & Prepositional-object & \\
\hline $\begin{array}{l}1,5 \\
11\end{array}$ & $\begin{array}{l}\text { The girl brought the fish the } \\
\text { broom. }\end{array}$ & $\begin{array}{l}\text { The girl brought the broom to } \\
\text { the fish. }\end{array}$ & $\begin{array}{l}\text { The girl hauled the } \\
\text { broom behind the } \\
\text { fish. }\end{array}$ \\
\hline $\begin{array}{l}1,5 \\
11\end{array}$ & $\begin{array}{l}\text { The woman brought the man } \\
\text { the ladder. }\end{array}$ & $\begin{array}{l}\text { The woman brought the ladder } \\
\text { to the man. }\end{array}$ & $\begin{array}{l}\text { The woman hauled } \\
\text { the ladder behind } \\
\text { the man. }\end{array}$ \\
\hline $\begin{array}{l}1,5 \\
11\end{array}$ & $\begin{array}{l}\text { The girl fed the duck the } \\
\text { cheese. }\end{array}$ & $\begin{array}{l}\text { The girl fed the cheese to the } \\
\text { duck. }\end{array}$ & $\begin{array}{l}\text { The girl spun the } \\
\text { cheese near the } \\
\text { duck. }\end{array}$ \\
\hline $\begin{array}{l}1,5 \\
11\end{array}$ & $\begin{array}{l}\text { The woman fed the goose the } \\
\text { strawberry. }\end{array}$ & $\begin{array}{l}\text { The woman fed the strawberry } \\
\text { to the goose. }\end{array}$ & $\begin{array}{l}\text { The woman spun the } \\
\text { strawberry near the } \\
\text { goose. }\end{array}$ \\
\hline $\begin{array}{l}1,5 \\
11\end{array}$ & $\begin{array}{l}\text { The boy gave the rooster the } \\
\text { lamp. }\end{array}$ & $\begin{array}{l}\text { The boy gave the lamp to the } \\
\text { rooster. }\end{array}$ & $\begin{array}{l}\text { The boy lugged the } \\
\text { lamp past the } \\
\text { rooster. }\end{array}$ \\
\hline $\begin{array}{l}1,5 \\
11\end{array}$ & $\begin{array}{l}\text { The girl gave the cowboy the } \\
\text { hammer. }\end{array}$ & $\begin{array}{l}\text { The girl gave the hammer to } \\
\text { the cowboy. }\end{array}$ & $\begin{array}{l}\text { The girl lugged the } \\
\text { hammer past the } \\
\text { cowboy. }\end{array}$ \\
\hline $\begin{array}{l}1,5 \\
11\end{array}$ & $\begin{array}{l}\text { The man handed the mouse the } \\
\text { spoon. }\end{array}$ & $\begin{array}{l}\text { The man handed the spoon to } \\
\text { the mouse. }\end{array}$ & $\begin{array}{l}\text { The man moved the } \\
\text { spoon beyond the } \\
\text { mouse. }\end{array}$ \\
\hline $\begin{array}{l}1,5 \\
11\end{array}$ & $\begin{array}{l}\text { The woman handed the } \\
\text { elephant the eggs. }\end{array}$ & $\begin{array}{l}\text { The woman handed the eggs } \\
\text { to the elephant. }\end{array}$ & $\begin{array}{l}\text { The woman moved } \\
\text { the eggs beyond the } \\
\text { elephant. }\end{array}$ \\
\hline $\begin{array}{l}1,5 \\
11\end{array}$ & $\begin{array}{l}\text { The boy lent the clown the } \\
\text { sled. }\end{array}$ & $\begin{array}{l}\text { The boy lent the sled to the } \\
\text { clown. }\end{array}$ & $\begin{array}{l}\text { The boy pulled the } \\
\text { sled toward the } \\
\text { clown. }\end{array}$ \\
\hline $\begin{array}{l}1,5 \\
11\end{array}$ & $\begin{array}{l}\text { The woman lent the wolf the } \\
\text { chair. }\end{array}$ & $\begin{array}{l}\text { The woman lent the chair to } \\
\text { the wolf. }\end{array}$ & $\begin{array}{l}\text { The woman pulled } \\
\text { the chair toward the } \\
\text { wolf. }\end{array}$ \\
\hline
\end{tabular}




\begin{tabular}{|c|c|c|c|}
\hline $\begin{array}{l}1,5 \\
11\end{array}$ & $\begin{array}{l}\text { The girl offered the squirrel the } \\
\text { bread. }\end{array}$ & $\begin{array}{l}\text { The girl offered the bread to } \\
\text { the squirrel. }\end{array}$ & $\begin{array}{l}\text { The girl dropped the } \\
\text { bread by the } \\
\text { squirrel. }\end{array}$ \\
\hline $\begin{array}{l}1,5 \\
11\end{array}$ & $\begin{array}{l}\text { The man offered the alligator } \\
\text { the hat. }\end{array}$ & $\begin{array}{l}\text { The man offered the hat to the } \\
\text { alligator. }\end{array}$ & $\begin{array}{l}\text { The man dropped } \\
\text { the hat by the } \\
\text { alligator. }\end{array}$ \\
\hline $\begin{array}{l}1,5 \\
11\end{array}$ & $\begin{array}{l}\text { The boy passed the chicken the } \\
\text { cake. }\end{array}$ & $\begin{array}{l}\text { The boy passed the cake to the } \\
\text { chicken. }\end{array}$ & $\begin{array}{l}\text { The boy pushed the } \\
\text { cake against the } \\
\text { chicken. }\end{array}$ \\
\hline $\begin{array}{l}1,5 \\
11\end{array}$ & $\begin{array}{l}\text { The man passed the lady the } \\
\text { cup. }\end{array}$ & $\begin{array}{l}\text { The man passed the cup to the } \\
\text { lady. }\end{array}$ & $\begin{array}{l}\text { The man pushed the } \\
\text { cup against the lady. }\end{array}$ \\
\hline $\begin{array}{l}1,5 \\
11\end{array}$ & $\begin{array}{l}\text { The boy read the bunny the } \\
\text { menu. }\end{array}$ & $\begin{array}{l}\text { The boy read the menu to the } \\
\text { bunny. }\end{array}$ & $\begin{array}{l}\text { The boy carried the } \\
\text { menu alongside the } \\
\text { bunny. }\end{array}$ \\
\hline $\begin{array}{l}1,5 \\
11\end{array}$ & $\begin{array}{l}\text { The woman read the frog the } \\
\text { newspaper. }\end{array}$ & $\begin{array}{l}\text { The woman read the } \\
\text { newspaper to the frog. }\end{array}$ & $\begin{array}{l}\text { The woman carried } \\
\text { the newspaper } \\
\text { alongside the frog. }\end{array}$ \\
\hline $\begin{array}{l}1,5, \\
11\end{array}$ & $\begin{array}{l}\text { The boy sent the butterfly the } \\
\text { basket. }\end{array}$ & $\begin{array}{l}\text { The boy sent the basket to the } \\
\text { butterfly. }\end{array}$ & $\begin{array}{l}\text { The boy lowered the } \\
\text { basket beside the } \\
\text { butterfly. }\end{array}$ \\
\hline $\begin{array}{l}1,5, \\
11\end{array}$ & The man sent the lion the box. & $\begin{array}{l}\text { The man sent the box to the } \\
\text { lion. }\end{array}$ & $\begin{array}{l}\text { The man lowered } \\
\text { the box beside the } \\
\text { lion. }\end{array}$ \\
\hline $\begin{array}{l}1,5 \\
11\end{array}$ & $\begin{array}{l}\text { The boy showed the penguin } \\
\text { the bicycle. }\end{array}$ & $\begin{array}{l}\text { The boy showed the bicycle to } \\
\text { the penguin. }\end{array}$ & $\begin{array}{l}\text { The boy dragged the } \\
\text { bicycle around the } \\
\text { penguin. }\end{array}$ \\
\hline $\begin{array}{l}1,5 \\
11\end{array}$ & $\begin{array}{l}\text { The girl showed the doctor the } \\
\text { bucket. }\end{array}$ & $\begin{array}{l}\text { The girl showed the bucket to } \\
\text { the doctor. }\end{array}$ & $\begin{array}{l}\text { The girl dragged the } \\
\text { bucket around the } \\
\text { doctor. }\end{array}$ \\
\hline $\begin{array}{l}1,5 \\
11\end{array}$ & $\begin{array}{l}\text { The girl sold the bear the } \\
\text { glasses. }\end{array}$ & $\begin{array}{l}\text { The girl sold the glasses to the } \\
\text { bear. }\end{array}$ & $\begin{array}{l}\text { The girl lifted the } \\
\text { glasses under the } \\
\text { bear. }\end{array}$ \\
\hline $\begin{array}{l}1,5, \\
11\end{array}$ & $\begin{array}{l}\text { The man sold the giraffe the } \\
\text { camera. }\end{array}$ & $\begin{array}{l}\text { The man sold the camera to } \\
\text { the giraffe. }\end{array}$ & $\begin{array}{l}\text { The man lifted the } \\
\text { camera under the } \\
\text { giraffe. }\end{array}$ \\
\hline
\end{tabular}




\begin{tabular}{|l|l|l|l|}
\hline $\begin{array}{l}1,5, \\
11\end{array}$ & $\begin{array}{l}\text { The man threw the pony the } \\
\text { crayon. }\end{array}$ & $\begin{array}{l}\text { The man threw the crayon to } \\
\text { the pony. }\end{array}$ & $\begin{array}{l}\text { The man raised the } \\
\text { crayon above the } \\
\text { pony. }\end{array}$ \\
\hline $\begin{array}{l}1,5, \\
11\end{array}$ & $\begin{array}{l}\text { The woman threw the bird the } \\
\text { ball. }\end{array}$ & $\begin{array}{l}\text { The woman threw the ball to } \\
\text { the bird. }\end{array}$ & $\begin{array}{l}\text { The woman raised } \\
\text { the ball above the } \\
\text { bird. }\end{array}$ \\
\hline
\end{tabular}

\section{Locatives}

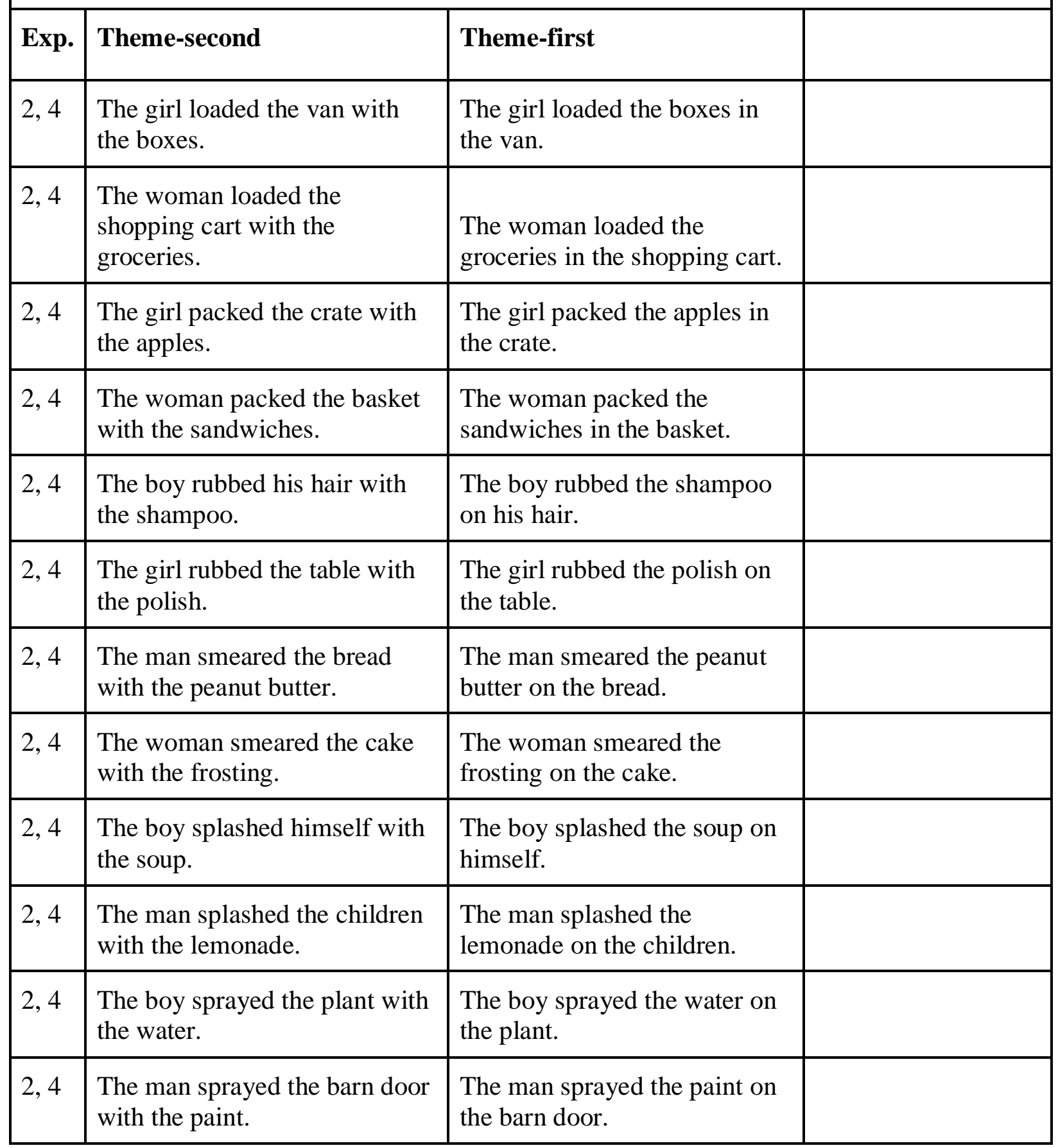




\begin{tabular}{|c|c|c|c|}
\hline 2,4 & $\begin{array}{l}\text { The boy stuffed the chest with } \\
\text { the toys. }\end{array}$ & $\begin{array}{l}\text { The boy stuffed the toys in the } \\
\text { chest. }\end{array}$ & \\
\hline 2,4 & $\begin{array}{l}\text { The girl stuffed the pillow with } \\
\text { the feathers. }\end{array}$ & $\begin{array}{l}\text { The girl stuffed the feathers in } \\
\text { the pillow. }\end{array}$ & \\
\hline 2,4 & $\begin{array}{l}\text { The man wrapped the present } \\
\text { with the tissue paper. }\end{array}$ & $\begin{array}{l}\text { The man wrapped the tissue } \\
\text { paper around the present. }\end{array}$ & \\
\hline 2,4 & $\begin{array}{l}\text { The woman wrapped the pizza } \\
\text { with the plastic wrap. }\end{array}$ & $\begin{array}{l}\text { The woman wrapped the } \\
\text { plastic wrap around the pizza. }\end{array}$ & \\
\hline \multicolumn{3}{|c|}{ Locatives (+animate destinations) } & \\
\hline Exp. & Theme-second & Theme-first & \\
\hline 3,8 & $\begin{array}{l}\text { The boy injected the dog with } \\
\text { the medicine. }\end{array}$ & $\begin{array}{l}\text { The boy injected the medicine } \\
\text { into the dog. }\end{array}$ & \\
\hline 3,8 & $\begin{array}{l}\text { The girl injected the patient } \\
\text { with the vaccine. }\end{array}$ & $\begin{array}{l}\text { The girl injected the vaccine } \\
\text { into the patient. }\end{array}$ & \\
\hline 3,8 & $\begin{array}{l}\text { The girl loaded the donkey } \\
\text { with the bags. }\end{array}$ & $\begin{array}{l}\text { The girl loaded the bags onto } \\
\text { the donkey. }\end{array}$ & \\
\hline 3,8 & $\begin{array}{l}\text { The woman loaded the } \\
\text { packmule with the luggage. }\end{array}$ & $\begin{array}{l}\text { The woman loaded the } \\
\text { luggage onto the packmule. }\end{array}$ & \\
\hline 3,8 & $\begin{array}{l}\text { The girl pumped the lab rat } \\
\text { with the steroids. }\end{array}$ & $\begin{array}{l}\text { The girl pumped the steroids } \\
\text { into the lab rat. }\end{array}$ & \\
\hline 3,8 & $\begin{array}{l}\text { The woman pumped the athlete } \\
\text { with the oxygen. }\end{array}$ & $\begin{array}{l}\text { The woman pumped the } \\
\text { oxygen into the athlete. }\end{array}$ & \\
\hline 3,8 & $\begin{array}{l}\text { The boy rubbed the client with } \\
\text { the oil. }\end{array}$ & $\begin{array}{l}\text { The boy rubbed the oil on the } \\
\text { client. }\end{array}$ & \\
\hline 3,8 & $\begin{array}{l}\text { The girl rubbed the toddler } \\
\text { with the lotion. }\end{array}$ & $\begin{array}{l}\text { The girl rubbed the lotion on } \\
\text { the toddler. }\end{array}$ & \\
\hline 3,8 & $\begin{array}{l}\text { The boy splashed the trainer } \\
\text { with the water. }\end{array}$ & $\begin{array}{l}\text { The boy splashed the water on } \\
\text { the trainer. }\end{array}$ & \\
\hline 3,8 & $\begin{array}{l}\text { The man splashed the student } \\
\text { with the chemicals. }\end{array}$ & $\begin{array}{l}\text { The man splashed the } \\
\text { chemicals on the student. }\end{array}$ & \\
\hline 3,8 & $\begin{array}{l}\text { The man splattered the artist } \\
\text { with the paint. }\end{array}$ & $\begin{array}{l}\text { The man splattered the paint } \\
\text { on the artist. }\end{array}$ & \\
\hline
\end{tabular}




\begin{tabular}{|c|c|c|}
\hline 3,8 & $\begin{array}{l}\text { The woman splattered the } \\
\text { assistant with the grease. }\end{array}$ & $\begin{array}{l}\text { The woman splattered the } \\
\text { grease on the assistant. }\end{array}$ \\
\hline 3,8 & $\begin{array}{l}\text { The boy sprayed the man with } \\
\text { the cologne. }\end{array}$ & $\begin{array}{l}\text { The boy sprayed the cologne } \\
\text { on the man. }\end{array}$ \\
\hline 3,8 & $\begin{array}{l}\text { The man sprayed the thief with } \\
\text { the mace. }\end{array}$ & $\begin{array}{l}\text { The man sprayed the mace on } \\
\text { the thief. }\end{array}$ \\
\hline 3,8 & $\begin{array}{l}\text { The man wrapped the baby in } \\
\text { the blanket. }\end{array}$ & $\begin{array}{l}\text { The man wrapped the blanket } \\
\text { around the baby. }\end{array}$ \\
\hline 3,8 & $\begin{array}{l}\text { The woman wrapped the boy } \\
\text { in the towel. }\end{array}$ & $\begin{array}{l}\text { The woman wrapped the } \\
\text { towel around the boy. }\end{array}$ \\
\hline \multicolumn{3}{|c|}{ Locatives (+animate themes) } \\
\hline Exp. & Theme-second & Theme-first \\
\hline 9 & $\begin{array}{l}\text { The man crammed the cell } \\
\text { with the prisoners. }\end{array}$ & $\begin{array}{l}\text { The man crammed the } \\
\text { prisoners into the cell. }\end{array}$ \\
\hline 9 & $\begin{array}{l}\text { The woman crammed the pot } \\
\text { with the lobsters. }\end{array}$ & $\begin{array}{l}\text { The woman crammed the } \\
\text { lobsters into the pot. }\end{array}$ \\
\hline 9 & $\begin{array}{l}\text { The girl draped the jungle gym } \\
\text { with the monkeys. }\end{array}$ & $\begin{array}{l}\text { The girl draped the monkeys } \\
\text { on the jungle gym. }\end{array}$ \\
\hline 9 & $\begin{array}{l}\text { The man draped the tree with } \\
\text { the sloths. }\end{array}$ & $\begin{array}{l}\text { The man draped the sloths on } \\
\text { the tree. }\end{array}$ \\
\hline 9 & $\begin{array}{l}\text { The girl loaded the trailer with } \\
\text { the horses. }\end{array}$ & $\begin{array}{l}\text { The girl loaded the horses } \\
\text { onto the trailer. }\end{array}$ \\
\hline 9 & $\begin{array}{l}\text { The woman loaded the tank } \\
\text { with the dolphins. }\end{array}$ & $\begin{array}{l}\text { The woman loaded the } \\
\text { dolphins into the tank. }\end{array}$ \\
\hline 9 & $\begin{array}{l}\text { The boy packed the kennel } \\
\text { with the puppies. }\end{array}$ & $\begin{array}{l}\text { The boy packed the puppies } \\
\text { into the kennel. }\end{array}$ \\
\hline 9 & $\begin{array}{l}\text { The girl packed the crate with } \\
\text { the chickens. }\end{array}$ & $\begin{array}{l}\text { The girl packed the chickens } \\
\text { into the crate. }\end{array}$ \\
\hline 9 & $\begin{array}{l}\text { The boy piled the log with the } \\
\text { ants. }\end{array}$ & $\begin{array}{l}\text { The boy piled the ants onto } \\
\text { the log. }\end{array}$ \\
\hline 9 & $\begin{array}{l}\text { The woman piled the car with } \\
\text { the children. }\end{array}$ & $\begin{array}{l}\text { The woman piled the children } \\
\text { into the car. }\end{array}$ \\
\hline
\end{tabular}




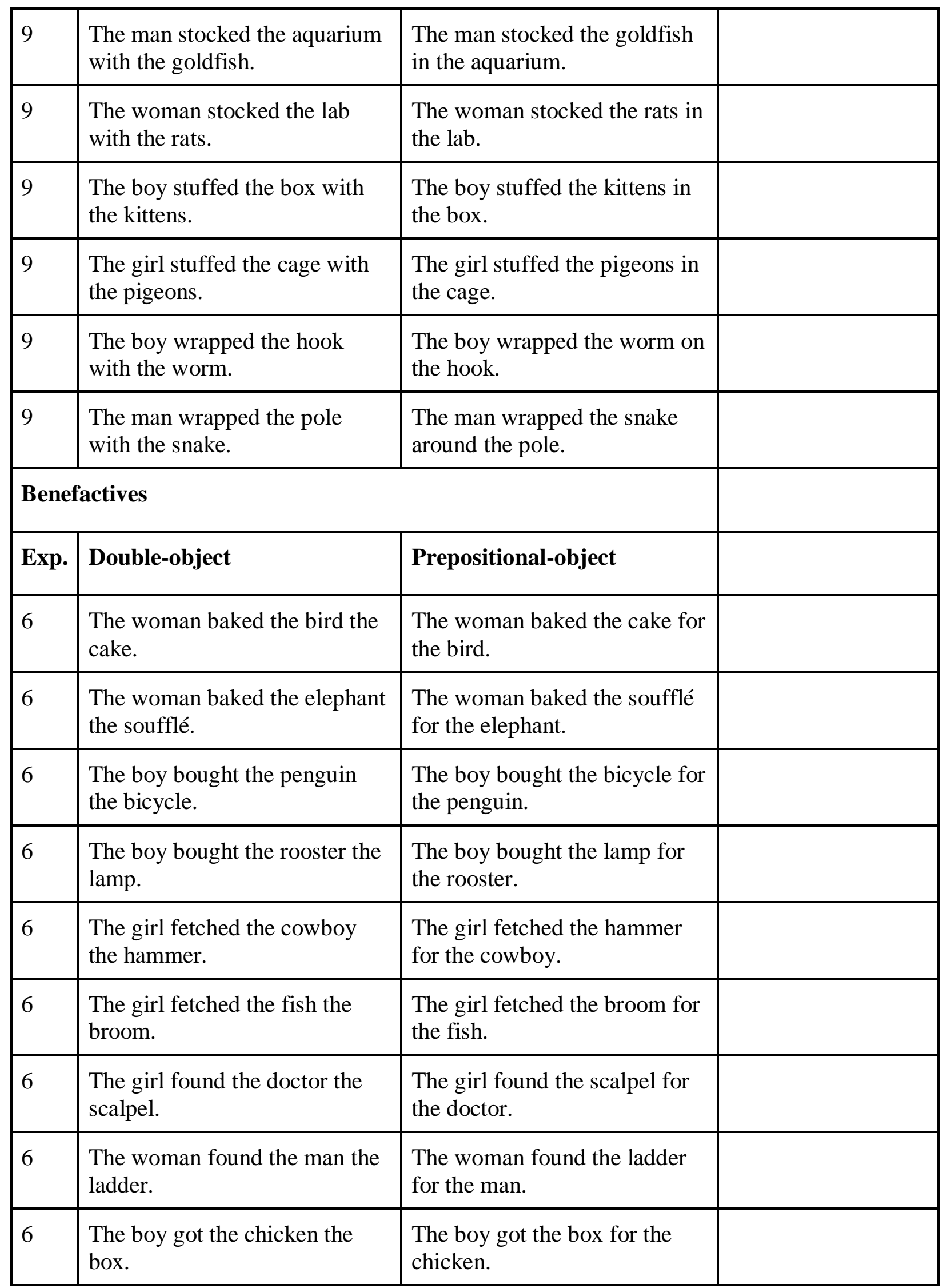




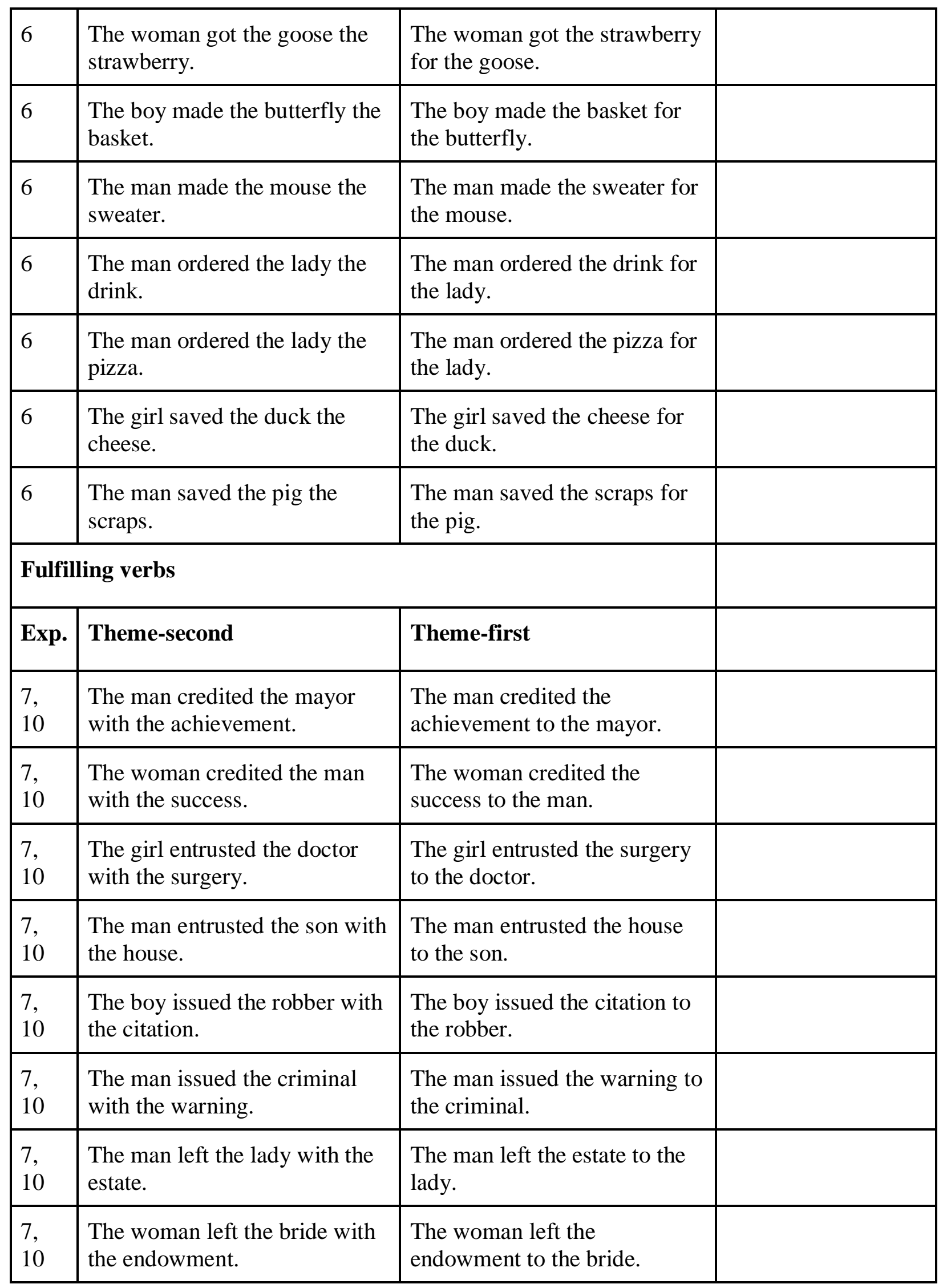




\begin{tabular}{|l|l|l|l|}
\hline $\begin{array}{l}7, \\
10\end{array}$ & $\begin{array}{l}\text { The boy presented the athlete } \\
\text { with the trophy. }\end{array}$ & $\begin{array}{l}\text { The boy presented the trophy } \\
\text { to the athlete. }\end{array}$ & \\
\hline 7, & $\begin{array}{l}\text { The woman presented the actor } \\
\text { with the award. }\end{array}$ & $\begin{array}{l}\text { The woman presented the } \\
\text { award to the actor. }\end{array}$ & \\
\hline 7, & $\begin{array}{l}\text { The boy provided the banker } \\
\text { with the funds. }\end{array}$ & $\begin{array}{l}\text { The boy provided the funds to } \\
\text { the banker. }\end{array}$ & \\
\hline 7, & $\begin{array}{l}\text { The boy provided the teacher } \\
\text { with the resources. }\end{array}$ & $\begin{array}{l}\text { The boy provided the } \\
\text { resources to the teacher. }\end{array}$ & \\
\hline 7, & $\begin{array}{l}\text { The girl served the juror with } \\
\text { the summons. }\end{array}$ & $\begin{array}{l}\text { The girl served the summons } \\
\text { to the juror. }\end{array}$ & \\
\hline 7, & $\begin{array}{l}\text { The woman served the witness } \\
\text { with the subpoena. }\end{array}$ & $\begin{array}{l}\text { The woman served the } \\
\text { subpoena to the witness. }\end{array}$ & \\
\hline 10 & $\begin{array}{l}\text { The girl supplied the contractor } \\
\text { with the materials. }\end{array}$ & $\begin{array}{l}\text { The girl supplied the materials } \\
\text { to the contractor. }\end{array}$ & $\begin{array}{l}\text { The girl supplied the tools to } \\
\text { the cowboy. }\end{array}$ \\
\hline 7, & $\begin{array}{l}\text { The girl supplied the cowboy } \\
\text { with the tools. }\end{array}$ & \\
\hline 10
\end{tabular}


Appendix B. Target animations by experiment.

\begin{tabular}{|c|c|}
\hline \multicolumn{2}{|l|}{ Datives } \\
\hline Exp. & Description \\
\hline $1,4,6-9,11$ & Boy bringing camel keys / keys to camel \\
\hline $1,4,6-9,11$ & Man feeding girl bagel / bagel to girl \\
\hline $1,4,6-9,11$ & Man giving dolphin flower / flower to dolphin \\
\hline $1,4,6-9,11$ & Boy handing fireman teapot / teapot to fireman \\
\hline $1,4,6-9,11$ & Girl passing cat money / money to cat \\
\hline $1,4,6-9,11$ & Woman sending horse clock / clock to horse \\
\hline $1,4,6-9,11$ & Woman showing owl picture / picture to owl \\
\hline $1,4,6-9,11$ & Girl throwing puppy muffin / muffin to puppy \\
\hline \multicolumn{2}{|l|}{ Locatives } \\
\hline Exp. & Description \\
\hline $2,3,5,10$ & Boy loading cart with suitcase / suitcase onto cart \\
\hline $2,3,5,10$ & Man packing backpack with books / books into backpack \\
\hline $2,3,5,10$ & Man rubbing hands with soap / soap on hands \\
\hline $2,3,5,10$ & Boy smearing wall with mud / mud on wall \\
\hline $2,3,5,10$ & Woman splashing floor with water / water onto floor \\
\hline $2,3,5,10$ & Girl spraying neck with perfume / perfume on neck \\
\hline $2,3,5,10$ & Girl stuffing closet with shoe / shoe into closet \\
\hline
\end{tabular}


\begin{tabular}{|l|l}
\hline $2,3,7,10$ & Woman wrapping child's arm with bandage / bandage around child's arm
\end{tabular} 
Appendix C. Supplementary material.

The data associated with this article can be found at https://doi.org/10.17605/OSF.IO/AHFKY. 